\title{
15. SEDIMENTARY SEQUENCE FROM SITES 875 AND 876, OUTER PERIMETER RIDGE, WODEJEBATO GUYOT ${ }^{1}$
}

\author{
Paul Enos, ${ }^{2}$ Gilbert F. Camoin, ${ }^{3}$ and Philippe Ebren ${ }^{3}$
}

\begin{abstract}
The outer perimeter ridge of Wodejebato Guyot consists of porous Maastrichtian skeletal calcarenite that directly overlies slightly altered basaltic basement. Three units are recognized: a lower porous, lightly cemented, skeletal calcarenite (LPSC); a thin, muddy, indurated, middle skeletal packstone (MIMSP) with rhodoliths and porous lithoclasts; and an upper, highly porous, lightly cemented, skeletal grainstone and packstone (UPSC). The carbonate surface was etched into relief, coated with manganese oxides, and veneered by late Paleocene to late Eocene pelagic carbonates. The skeletal sand pile is composed mainly of rudist and other mollusk fragments, benthic foraminifers, and red algae. Echinoderms, corals, minor calcareous sponges, dasyclad algae, and planktonic foraminifers are other components. The sand probably accumulated as a spit in front of the inner perimeter ridge during transgression following a lowering of relative sea level. The leached lithoclasts in MIMSP were probably eroded from the inner perimeter ridge and deposited along with mud and rhodoliths on the adjacent shallow slope.

The extensive moldic porosity of LPSC and UPSC probably developed by cold-seawater dissolution of aragonitic skeletons throughout the Cenozoic with concomitant light cementation by calcite. The surface relief on the ridge predates drowning and is interpreted as a microkarst formed during exposure to meteoric water. Some of the moldic porosity conceivably formed during this brief event.
\end{abstract}

\section{INTRODUCTION}

Wodejebato Guyot, the drowned sibling of Pikinni Atoll, Marshall Islands, was " . . . interpreted according to the classical features of a drowned atoll: ... . central pelagic cap, ... exposed reef rims, and the radial gullies ..." (Premoli Silva, Haggerty, Rack, et al., 1993, p. 147). Along much of the north and east sides of Wodejebato Guyot, two parallel perimeter ridges are present, generally separated by a narrow trough about $50 \mathrm{~m}$ deep (Fig. 1). Coring at Site 874 and, eventually, Site 877 confirmed that the higher inner perimeter ridge was essentially a constructional reef rim. The outer, less continuous, perimeter ridge appeared in seismic profiles as a constructional feature (Premoli Silva, Haggerty, Rack, et al., 1993, p. 256), morphologically rather similar to the inner ridge (Figs. 1 and 2; Bergersen, this volume). These features led to speculation during drilling that the outer perimeter ridge was also a reef rim, probably younger than the inner reef rim. Site 875 was drilled to determine the composition and origin of the outer perimeter ridge, determine its relationship to the evolution of the guyot, and evaluate the vertical tectonic history of the platform, amongst other objectives (Premoli Silva, Haggerty, Rack, et al., 1993, p. 256). Against this background, it was a considerable surprise to core a monotonous sequence of skeletal sand at Site 875. In disbelief, a second hole was drilled $1.67 \mathrm{~km}$ northwest along the ridge trend to investigate the variability of the outer perimeter ridge and to establish the characteristics of the facies and facies changes with time (Premoli Silva, Haggerty, Rack, et al., 1993, p. 256). Site 876 produced a sedimentary sequence that is a near clone of Site 875 , confirming that the outer ridge originated as a pile of clean skeletal sand. The rocks at the two sites are so similar that it is expedient to describe them together and note the minor differences between the successions.

The outer perimeter ridge is more than $3 \mathrm{~km}$ long at the drilling sites; it merges with the slope of the inner perimeter ridge to the

\footnotetext{
${ }^{1}$ Haggerty, J.A., Premoli Silva, I., Rack, F., and McNutt, M.K. (Eds.), 1995. Proc. ODP, Sci. Resuits, 144: College Station, TX (Ocean Drilling Program).

2 Department of Geology, University of Kansas, 120 Lindley Hall, Lawrence, KS 66045, U.S.A.

${ }^{3}$ Centre de Sédimentologie et Paléontologie, URA 1208 du CNRS, Université de Provence, 3 Place Victor Hugo, F-13331 Marseille Cedex 3, France.
}

northwest (Fig. 1; Premoli Silva, Haggerty, Rack, et al., 1993, p. 217) but has not been mapped in detail elsewhere. The summit is 200 to $700 \mathrm{~m}$ wide (Bergersen, this volume) and it rises to about $50 \mathrm{~m}$ above the trough separating the parallel perimeter ridges (Fig. 1). The seaward slopes are closely comparable to those of the inner perimeter ridge (Fig. 2), which range from $4^{\circ}$ (Fig. 2, a-a') to $15^{\circ}$ (Fig. 2, d-d' ) (Bergersen, this volume). At the paired drill Sites 874 and 875 , the outer ridge is $34 \mathrm{~m}$ lower in elevation than the inner ridge. Site 876 is $44 \mathrm{~m}$ lower than Site 877 on the inner ridge.

The sedimentary rocks of the outer perimeter ridge are 126 to $145.5 \mathrm{~m}$ of highly porous, lightly cemented carbonate sand consisting of skeletal grains and hollow micrite rinds of dissolved grains. The uniformity is broken by a thin interval (8.4-10 m thick) of somewhat muddier, better lithified skeletal sand that incorporates some wackestone. This punctuation defines three units of platform carbonates. The platform units are Lower Porous Skeletal Calcarenite (LPSC), Subunit IIC of the Initial Reports; Middle Indurated, Muddy Skeletal Packstone (MIMSP), Subunit IIB of the Initial Reports; and Upper Porous Skeletal Calcarenite (UPSC), Subunit IIA of the Initial Reports (Fig. 3). The platform surface was encrusted by manganese and veneered by early Tertiary pelagic carbonates (Unit I of Premoli Silva, Haggerty, Rack, et al., 1993, p. 258).

Basalts of the volcanic core of Wodejebato were encountered beneath the carbonate section at 126 mbsf in Hole $875 \mathrm{C}$ and at 145.5 mbsf in Hole 876A. These depths, based on downhole increases in drilling times (Premoli Silva, Haggerty, Rack, et al., 1993, p. 283), are a few meters below where the limestone-basalt contact would be placed by ODP convention of hanging partial recovery at the top of the cored interval, but they are probably more accurate. No downhole logs were obtained at these sites because of poor hole conditions and time constraints.

The variegated claystones and dark shales cored immediately above basement at the other Wodejebato sites, including 874 and 877 on the inner perimeter ridge, were lacking at both sites.

Highly vesicular, alkali olivine basalt at Site 875 showed significant alteration and addition of $1 \%$ to $2 \%$ secondary pyrite along fractures near the top. Limestones just above the contact also contain several percent pyrite that clearly postdates cementation and dissolution (e.g., interval 144-875C-14M-1, 56-59 cm). In contrast, the uppermost basalt at Site 876 is very fine grained and brownish in 


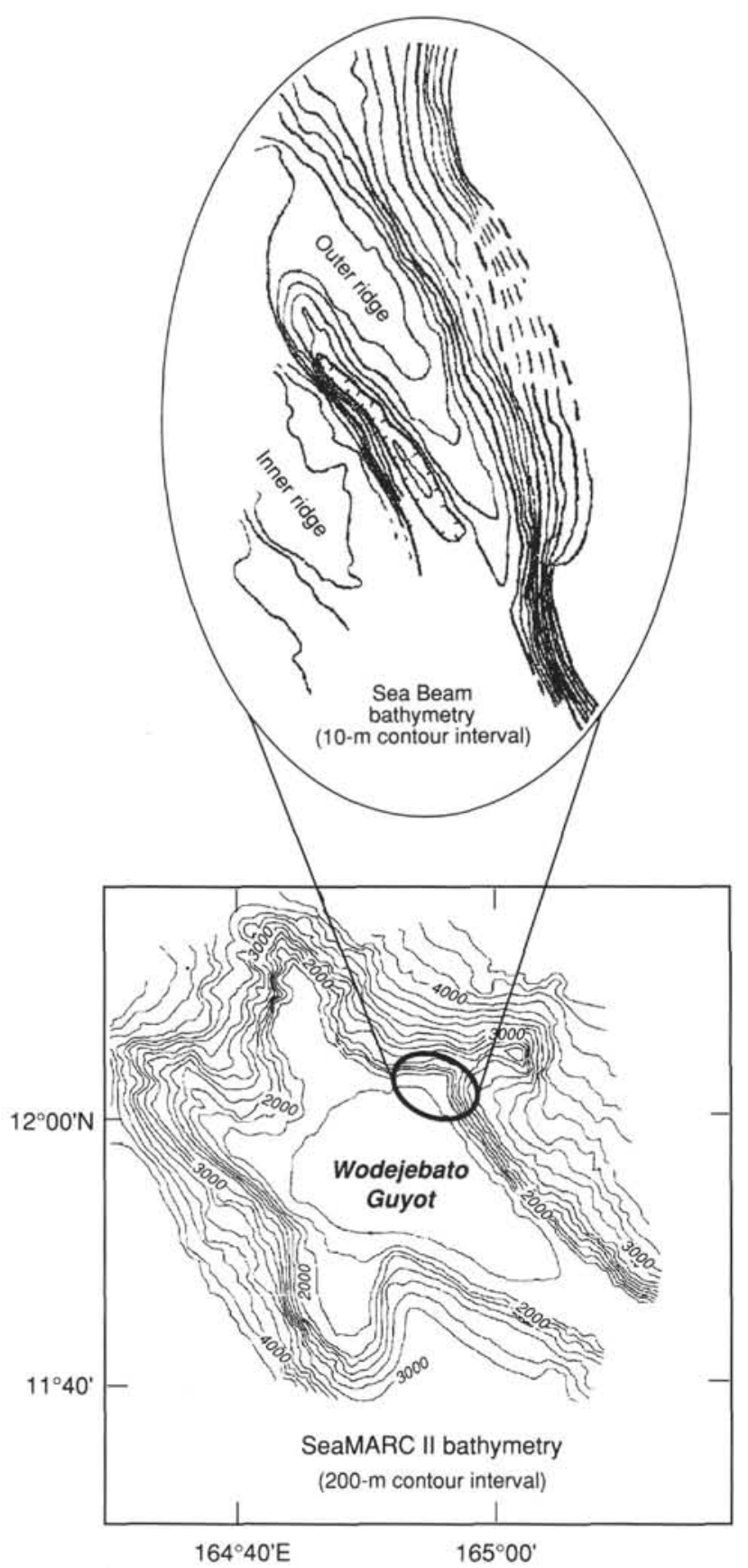

Figure 1. Location and bathymetry of Wodejebato Guyot, Marshall Islands. Inset is bathymetry of the outer perimeter ridge (Premoli Silva, Haggerty, Rack, et al., 1993, p. 214).

color, suggesting brief subaerial weathering at this slightly lower elevation (Premoli Silva, Haggerty, Rack, et al., 1993, p. 279). Reworked pebbles of basalt were recovered at the base of the sedimentary section at both sites (144-875C-14M-1, 62-65 cm [126 mbsf]; 144-876A-15R-1, 12-18 cm [145.5 mbsf]). Very pale brown (10YR $8 / 3$ and $7 / 3$ ) and brownish yellow (10YR 6/6) colors encountered at the base of the section of generally white limestone in Hole $875 \mathrm{C}$ (interval 144-875C-14M-1, 18-62 cm) and near the base in Hole $876 \mathrm{~A}$ (intervals $144-876 \mathrm{~A}-13 \mathrm{R}-1,0-33 \mathrm{~cm}$, and $-14 \mathrm{R}-1,0-83 \mathrm{~cm}$ ) may reflect iron derived from the underlying basaltic basement. The initially porous micrite rinds of most skeletal grains are stained brownish yellow.

\section{LOWER POROUS SKELETAL CALCARENITE (LPSC)}

Skeletal grainstone and packstone with extensive moldic porosity overlie the basaltic basement. Unit thickness is $12.1 \mathrm{~m}$ in Hole $875 \mathrm{C}$ but $37.5 \mathrm{~m}$ in Hole $876 \mathrm{C}$. This is the only dramatic thickness change between the two sites. It appears to slightly overcompensate for the deeper basement at Site 876. The top of LPSC would have sloped southeastward from $108 \mathrm{mbsf}$ at Site 876 to $113.9 \mathrm{mbsf}$ at Site 875 , perhaps indicating that the southeastward slope of the outer perimeter ridge was initiated by differential sedimentation at this time. This unit appears to be entirely Maastrichtian in age (Erba et al., this volume).

Thin sections from this interval are 53\% skeletal grainstone and $47 \%$ skeletal packstone. However, Site 876 is $75 \%$ packstone in 8 samples, whereas Site 875 is $70 \%$ grainstone in 13 samples. It is difficult to know whether this difference is significant, owing to the small number of samples and several operators. Grain size is coarse sand. Sorting is generally good, although admixtures of coarser skeletal fragments occur locally and mud is present in the packstone intervals. Skeletal components (Table 1) are predominately larger benthic foraminifers $(33.1 \%)$, mollusk fragments $(27.6 \%$, including $14.7 \%$ rudists), and red algae $(17.6 \%)$. Mollusks, mainly rudists, increase abruptly at the base of Hole $875 \mathrm{C}$, largely at the expense of foraminifers (Fig. 4). Echinoderms average $8.9 \%$ of the skeletal component. Minor constituents are corals $(2.0 \%)$ and ostracodes $(0.2 \%)$. Planktonic foraminifers are also a minor component $(0.4 \%)$. They were noted in only 3 samples near the top of the unit in Hole $875 \mathrm{C}$ (Premoli Silva, Haggerty, Rack, et al., 1993, p. 271), but they were present in all shore-based samples from Hole 876A.

Muddy matrix averages $7.3 \% \pm 12.9 \%$ (Table 2 and Fig. 5). This estimate is appreciably less than the shipboard estimate of $11.8 \% \pm$ $15.0 \%$ (Premoli Silva, Haggerty, Rack, et al., 1993, p. 266) because micrite envelopes were included as mud in many of those estimates, although clearly they should be counted as skeletal components. Peloids are a relatively minor component $(0.3 \% \pm 0.7 \%$; Table 2$)$. Closely packed intraclasts of laminated wackestone occur in a grainy matrix at interval 144-875C-13M-1, 66-72 cm (Premoli Silva, Haggerty, Rack, et al., 1993, p. 268, fig. 11). These overlie an apparent erosion surface marked by truncated grains and encrustation by red algae.

Porosity is very high throughout LPSC: six samples ranged from $19.1 \%$ to $39.5 \%$ porosity, averaging $30.9 \pm 7.5 \%$ (Premoli Silva, Haggerty, Rack, et al., 1993, pp. 267 and 280). Thin-section estimates indicate $25.4 \% \pm 12.4 \%$ porosity; about $53 \%$ of the porosity is secondary, owing to dissolution that produced skeletal molds and a few vugs (Table 2 and Fig. 6). The primary porosity is interparticle with minor contributions from intraparticle pores.

Cementation is light in LPSC; however, at $12.9 \% \pm 10.3 \%$ of bulk volume, it is nearly twice as abundant as in UPSC $(6.7 \%$; Table 2 and Fig. 5). Cements are finely crystalline, bladed crusts of limpid calcite with acute pyramidal terminations and uniform extinction (Fig. 7). This is the dominant cement throughout the outer perimeter ridge; $78 \%$ is in primary pores; $22 \%$ is secondary pores. Less common $(22 \%$ of the total cement) is medium crystalline, equant calcite that forms syntaxial overgrowths on mollusks, foraminifers, and echinoderms (Fig. 6). It is confined to primary, intergranular pores.

The contact between LPSC and the overlying muddier limestone was not recovered at Site 875 and is represented only by drilling pebbles in Hole 876A; therefore, its character is unknown.

\section{INDURATED MUDDY SKELETAL PACKSTONE (MIMSP)}

The only variation from clean skeletal sands within the outer perimeter ridge is a thin interval of predominately skeletal packstone and floatstone, 8.4 to $10 \mathrm{~m}$ thick. It is marked by an interval of significantly slower drilling (Premoli Silva, Haggerty, Rack, et al., 1993, pp. 266 and 283), reflecting generally greater induration. Because of 

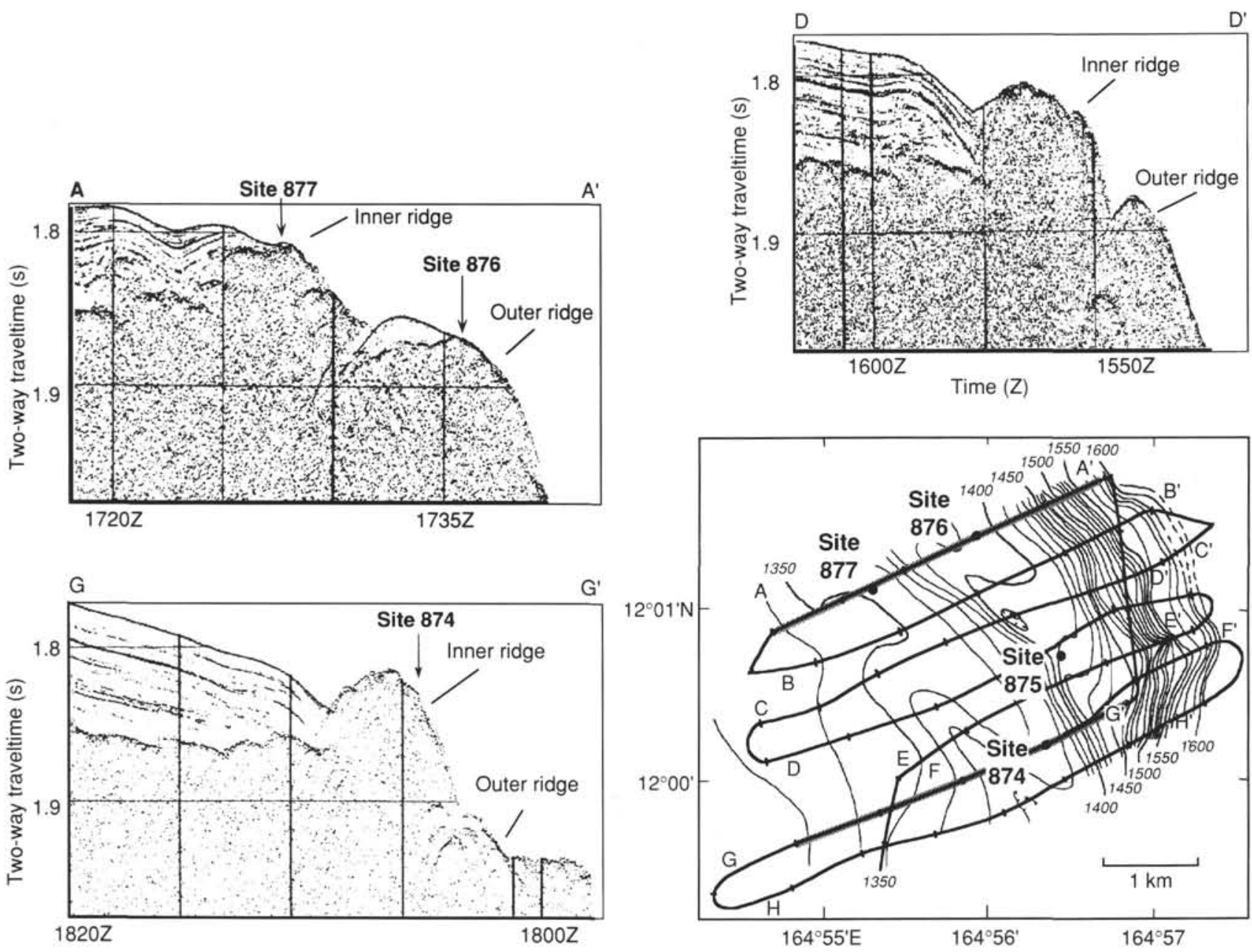

Figure 2. Profiles of perimeter ridges on the northeast margin of Wodejebato; 3.5-kHz echo-sounder profiles (modified from Premoli Silva, Haggerty, Rack, et al., 1993, pp. 216-217).

poor recovery and the lack of downhole logs, drilling rates were used to define unit boundaries. Lithologies noted in thin sections from this interval are packstone $(60 \%)$, floatstone $(27 \%)$, grainstone $(10 \%)$, and wackestone $(3 \%)$. This hint at diversity greatly understates the delightful complexity of this unit.

Skeletal constituents from thin-section counts and estimates include the familiar players from the other units (LPSC and UPSC) in proportions that are not markedly different (Table 1). Mollusks constitute $19.9 \%$ of the skeletal debris, benthic foraminifers $36.2 \%$, and red algae $21.9 \%$ (Table 1). Corals constitute $6.4 \%$, greater than in LSPC. Calcareous sponges (stromatoporoids, $2.5 \%$ ), echinoderms $(3.1) \%$, ostracodes $(0.2 \%)$, and planktonic foraminifers $(0.5 \%)$ are also represented. A significant difference from the rest of the sequence is the importance of rhodoliths, consortia of encrusting organisms dominated by coralline and squamaracian red algae, but typically including a variety of other encrusters such as foraminifers, corals, bryozoans, and unidentified forms (Fig. 8). Rhodoliths were prominent in five of seven thin sections examined post cruise from Hole 876A. They were under appreciated in shipboard examinations and are apparently less prominent in Hole $875 \mathrm{C}$, but they were noted in core descriptions from intervals $144-875 \mathrm{C}-12 \mathrm{M}-2,8-15$ and $33-49 \mathrm{~cm}$, and from intervals 144-876A-10R-1, 0-40 cm, and -11R-1, 85-112 cm.

Mud content is $13.4 \%$, significantly greater than in the calcarenite units (Table 2). Peloids, which include probable fecal pellets and micritized skeletal grains, contribute $11.1 \%$ of the bulk volume, also much greater than in the adjacent units.
Some sedimentary structures are visible in this unit, in contrast to the coarser, better sorted calcarenites above and below. Distinct burrows were noted at several intervals. A peloidal packstone with millimeter-scale cross-lamination dipping $8^{\circ}$ to $10^{\circ}$ was recovered from interval 144-876A-11R-1, 135-140 cm. This sample was a cylinder, long enough that it would not have been inverted nor stratigraphically mixed in the core barrel (Premoli Silva, Haggerty, Rack, et al., 1993, p. 11). The ovoid peloids, 50 to $150 \mu \mathrm{m}$ in diameter, form micrograded laminae that are draped by even thinner muddy laminae (Fig. 9). A few microscours are filled by slightly steeper laminae of the same type. Calcispheres, coccoliths, and silt-sized skeletal fragments are mixed with the peloids and mud. Both the structures and the lithology are unique among samples recovered from Wodejebato Guyot.

Several suggestive lithologic contracts were observed within the unit, despite recovery of only $13 \%$. At interval $144-876 \mathrm{~A}-10 \mathrm{R}-1,4 \mathrm{~cm}$, a scalloped contact with $1 \mathrm{~cm}$ of relief suggests dissolution of grains beneath the contact (true orientation is unknown, however). A wavy horizon $26 \mathrm{~cm}$ lower was possibly encrusted by a coral. These suggest either synsedimentary marine cementation to form hard grounds or subaerial exposure. Lamellar stromatoporoids, likely encrusters, were identified from five intervals within MIMSP in Hole 876A (Premoli Silva, Haggerty, Rack, et al., 1993, p. 262), but no distinct surfaces were identified as being encrusted. No comparable intervals were identified in Hole 875C. Two intervals of well-cemented skeletal lithoclasts in rudstone at the base of the overlying calcarenite unit (144$875 \mathrm{C}-12 \mathrm{M}-1,112-118$ and $121-125 \mathrm{~cm}$ ) suggest that the top of MIMSP 


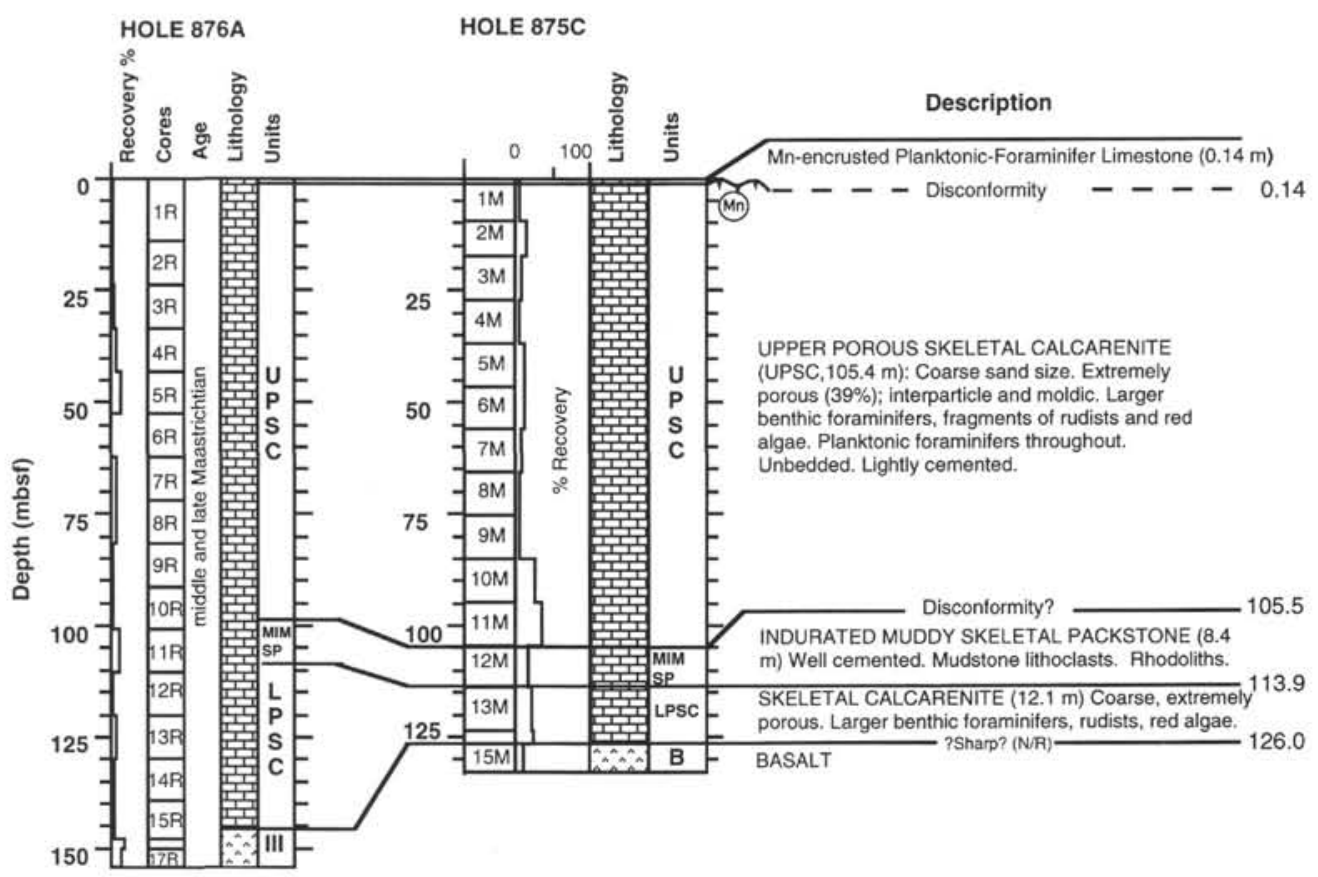

Figure 3. Lithostratigraphic summary and correlation between Holes 876 A and 875C. Depth and thickness values are from Hole 875C (modified from Premoli Silva, Haggerty, Rack, et al., 1993, p. 261).

Table 1. Skeletal components (percent) for Holes $875 \mathrm{C}$ and $876 \mathrm{~A}$.

\begin{tabular}{|c|c|c|c|c|c|c|c|c|c|c|c|c|c|}
\hline & & $\begin{array}{r}\text { Red } \\
\text { algae }\end{array}$ & $\begin{array}{l}\text { Green } \\
\text { algac }\end{array}$ & $\begin{array}{c}\text { Benthic } \\
\text { foraminifers }\end{array}$ & $\begin{array}{c}\text { Planktonic } \\
\text { foraminifers }\end{array}$ & Corals & Rudists & $\begin{array}{c}\text { Mollusk } \\
\text { fragments }\end{array}$ & Gastropods & Ostracodes & Echinoderms & $\begin{array}{c}\text { Micrite } \\
\text { envelope } \\
\text { and } \\
\text { unknown }\end{array}$ & $\begin{array}{l}\text { Miscellaneous } \\
\text { skeletal }\end{array}$ \\
\hline $\begin{array}{l}\text { Hole 875C: } \\
\text { UPSC } \\
N=48\end{array}$ & $\begin{array}{c}\text { Mean } \\
\text { SD }\end{array}$ & $\begin{array}{r}19.7 \\
8.2\end{array}$ & $\begin{array}{l}0.2 \\
1.5\end{array}$ & $\begin{array}{l}25.4 \\
15.5\end{array}$ & $\begin{array}{l}0.2 \\
0.5\end{array}$ & $\begin{array}{r}8.1 \\
10.4\end{array}$ & $\begin{array}{l}26.1 \\
17.6\end{array}$ & $\begin{array}{l}5.1 \\
8.8\end{array}$ & $\begin{array}{l}0.4 \\
1.0\end{array}$ & $\begin{array}{l}0.0 \\
0.0\end{array}$ & $\begin{array}{r}10.3 \\
5.2\end{array}$ & $\begin{array}{l}3.1 \\
7.4\end{array}$ & $\begin{array}{l}1.4 \\
6.8\end{array}$ \\
\hline $\begin{array}{l}\text { MIMSP } \\
N=4\end{array}$ & $\begin{array}{l}\text { Mean } \\
\text { SD }\end{array}$ & $\begin{array}{l}22.7 \\
15.4\end{array}$ & $\begin{array}{l}0.0 \\
0.0\end{array}$ & $\begin{array}{l}24.8 \\
20.1\end{array}$ & $\begin{array}{l}1.0 \\
1.9\end{array}$ & $\begin{array}{r}9.2 \\
10.8\end{array}$ & $\begin{array}{l}33.7 \\
23.5\end{array}$ & $\begin{array}{l}2.4 \\
2.9\end{array}$ & $\begin{array}{l}1.2 \\
2.4\end{array}$ & $\begin{array}{l}0.8 \\
1.6\end{array}$ & $\begin{array}{l}4.0 \\
1.6\end{array}$ & $\begin{array}{l}0.0 \\
0.0\end{array}$ & $\begin{array}{l}0.0 \\
0.0\end{array}$ \\
\hline $\begin{array}{l}\text { LPSC } \\
N=15\end{array}$ & $\begin{array}{l}\text { Mean } \\
\text { SD }\end{array}$ & $\begin{array}{r}20.0 \\
8.4\end{array}$ & $\begin{array}{l}0.1 \\
0.3\end{array}$ & $\begin{array}{l}29.4 \\
18.8\end{array}$ & $\begin{array}{l}0.4 \\
1.7\end{array}$ & $\begin{array}{l}2.9 \\
4.5\end{array}$ & $\begin{array}{l}22.2 \\
22.6\end{array}$ & $\begin{array}{r}7.9 \\
12.1\end{array}$ & $\begin{array}{l}0.3 \\
0.8\end{array}$ & $\begin{array}{l}0.4 \\
1.4\end{array}$ & $\begin{array}{r}10.1 \\
6.3\end{array}$ & $\begin{array}{r}5.9 \\
11.4\end{array}$ & $\begin{array}{l}0.5 \\
1.1\end{array}$ \\
\hline $\begin{array}{l}\text { Hole 876A: } \\
\text { UPSC } \\
N=27\end{array}$ & $\begin{array}{c}\text { Mean } \\
\text { SD }\end{array}$ & $\begin{array}{l}20.1 \\
17.4\end{array}$ & $\begin{array}{l}0.0 \\
0.0\end{array}$ & $\begin{array}{l}17.1 \\
10.0\end{array}$ & $\begin{array}{l}0.6 \\
0.8\end{array}$ & $\begin{array}{r}3.5 \\
13.1\end{array}$ & $\begin{array}{r}10.1 \\
9.3\end{array}$ & $\begin{array}{l}26.0 \\
17.4\end{array}$ & $\begin{array}{l}0.6 \\
1.5\end{array}$ & $\begin{array}{l}0.0 \\
0.0\end{array}$ & $\begin{array}{l}4.3 \\
3.2\end{array}$ & $\begin{array}{l}14.6 \\
14.0\end{array}$ & $\begin{array}{r}3.1 \\
12.0\end{array}$ \\
\hline $\begin{array}{l}\text { MIMSP } \\
N=13\end{array}$ & $\begin{array}{c}\text { Mean } \\
\text { SD }\end{array}$ & $\begin{array}{l}21.6 \\
18.5\end{array}$ & $\begin{array}{l}0.0 \\
0.0\end{array}$ & $\begin{array}{l}39.6 \\
19.7\end{array}$ & $\begin{array}{l}0.3 \\
0.6\end{array}$ & $\begin{array}{r}5.5 \\
13.2\end{array}$ & $\begin{array}{l}3.9 \\
8.3\end{array}$ & $\begin{array}{l}10.4 \\
12.0\end{array}$ & $\begin{array}{l}0.3 \\
1.0\end{array}$ & $\begin{array}{l}0.0 \\
0.0\end{array}$ & $\begin{array}{l}2.8 \\
3.4\end{array}$ & $\begin{array}{l}12.3 \\
22.9\end{array}$ & $\begin{array}{l}3.3 \\
9.3\end{array}$ \\
\hline $\begin{array}{l}\text { LPSC } \\
N=8\end{array}$ & $\begin{array}{l}\text { Mean } \\
\text { SD }\end{array}$ & $\begin{array}{r}13.2 \\
7.5\end{array}$ & $\begin{array}{l}0.0 \\
0.0\end{array}$ & $\begin{array}{l}40.1 \\
11.5\end{array}$ & $\begin{array}{l}0.4 \\
0.7\end{array}$ & $\begin{array}{l}0.3 \\
0.6\end{array}$ & $\begin{array}{l}0.7 \\
1.4\end{array}$ & $\begin{array}{l}19.1 \\
13.8\end{array}$ & $\begin{array}{l}2.7 \\
5.3\end{array}$ & $\begin{array}{l}0.0 \\
0.0\end{array}$ & $\begin{array}{l}6.7 \\
4.8\end{array}$ & $\begin{array}{l}13.8 \\
11.5\end{array}$ & $\begin{array}{l}3.0 \\
3.4\end{array}$ \\
\hline $\begin{array}{c}\text { Holes } 875 \mathrm{C} \\
\text { USPC } \\
N=75\end{array}$ & $\begin{array}{l}\text { and } 876 \mathrm{~A} \\
\text { Mean } \\
\text { SD }\end{array}$ & $\begin{array}{l}19.9 \\
12.2\end{array}$ & $\begin{array}{l}0.2 \\
1.2\end{array}$ & $\begin{array}{l}22.4 \\
14.3\end{array}$ & $\begin{array}{l}0.3 \\
0.7\end{array}$ & $\begin{array}{r}6.4 \\
11.6\end{array}$ & $\begin{array}{l}20.3 \\
16.9\end{array}$ & $\begin{array}{l}12.6 \\
16.0\end{array}$ & $\begin{array}{l}0.5 \\
1.2\end{array}$ & $\begin{array}{l}0.0 \\
0.0\end{array}$ & $\begin{array}{l}8.2 \\
5.4\end{array}$ & $\begin{array}{r}7.2 \\
11.6\end{array}$ & $\begin{array}{l}2.0 \\
9.0\end{array}$ \\
\hline $\begin{array}{l}\text { MIMSP } \\
N=17\end{array}$ & $\begin{array}{l}\text { Mean } \\
\text { SD }\end{array}$ & $\begin{array}{l}21.9 \\
17.4\end{array}$ & $\begin{array}{l}0.0 \\
0.0\end{array}$ & $\begin{array}{l}36.2 \\
20.2\end{array}$ & $\begin{array}{l}0.5 \\
1.0\end{array}$ & $\begin{array}{r}6.4 \\
12.4\end{array}$ & $\begin{array}{l}10.9 \\
18.0\end{array}$ & $\begin{array}{r}8.5 \\
11.1\end{array}$ & $\begin{array}{l}0.5 \\
1.4\end{array}$ & $\begin{array}{l}0.2 \\
0.8\end{array}$ & $\begin{array}{l}3.1 \\
3.1\end{array}$ & $\begin{array}{r}9.4 \\
20.6\end{array}$ & $\begin{array}{l}2.5 \\
8.2\end{array}$ \\
\hline $\begin{array}{l}\text { LSPC } \\
N=23\end{array}$ & $\begin{array}{l}\text { Mean } \\
\text { SD }\end{array}$ & $\begin{array}{r}17.6 \\
8.6\end{array}$ & $\begin{array}{l}0.0 \\
0.2\end{array}$ & $\begin{array}{l}33.1 \\
17.1\end{array}$ & $\begin{array}{l}0.4 \\
1.4\end{array}$ & $\begin{array}{l}2.0 \\
3.8\end{array}$ & $\begin{array}{l}14.7 \\
20.9\end{array}$ & $\begin{array}{l}11.8 \\
13.6\end{array}$ & $\begin{array}{l}1.1 \\
3.3\end{array}$ & $\begin{array}{l}0.2 \\
1.2\end{array}$ & $\begin{array}{l}8.9 \\
5.9\end{array}$ & $\begin{array}{r}8.6 \\
11.8\end{array}$ & $\begin{array}{l}1.4 \\
2.5\end{array}$ \\
\hline
\end{tabular}

Note: $N=$ number of samples, and $\mathrm{SD}=$ standard deviation.

may have been lithified before deposition of the overlying unit. Unfortunately, the actual contact was reduced to drilling pebbles.

Porosity within the skeletal carbonates of MIMSP is appreciably less than in the rest of the rocks of the outer perimeter ridge (Table 2). Primary porosity is limited to an average of $2.6 \%$; mud and cements occlude most of the intergranular space. Molds contribute about $4 \%$ porosity.

Cement is appreciably more abundant (23\%) in MIMSP than in adjacent units in Hole 876A (Table 2) despite the higher content of mud, which also occupies intergranular pores and tends to retard early cementation, and the lower absolute volume of secondary porosity as a site for cement growth. This is consistent with the increased drilling time in this interval. In contrast, the estimated volume of cement present in MIMSP in Hole $875 \mathrm{C}$ is actually less than in adjacent units (Table 2), although core descriptions indicate greater induration, at least at the top. Only two relevant thin sections were available from this interval in Hole $875 \mathrm{C}$, but it appears that the cause of increased drilling time may lie elsewhere (see below).

The initial cement in 4 samples (out of 13) from Hole 876A was an isopachous crusts of cloudy, fibrous calcite with sweeping extinc- 
tion indicating convergent optic axes. These are the characteristics of radiaxial fibrous calcite (Bathurst, 1975, p. 426). Radiaxial fibrous cement occupies $22.7 \%$ of the bulk volume in these samples. Of this volume, $3 \%$ is secondary. The only cement in most other samples is medium-crystalline, generally limpid, bladed crystals with uniform extinction. These are nearly identical to the major cement in the other units, except that the crystals are somewhat larger, and they locally grade into coarsely crystalline, equant, limpid crystals that fill all available pore space.

Internal sediment consisting of peloidal packstone with foraminifers and fragments of other skeletons overlies the radiaxial fibrous cement in several samples. In one sample (144-876A-11R-2, 14-23 $\mathrm{cm}$ ), a second generation of internal sediment, an ostracode packstone, overlies the limpid, bladed cement as well.

What else is new in this unit? In the Initial Reports volume, considerable attention was devoted to an $18-\mathrm{cm}$ interval of burrowed lime mudstone and wackestone bearing molds of small gastropods, ostracodes, and discorbid foraminifers (interval 144-875C-12M-2, 15-33 cm; Premoli Silva, Haggerty, Rack, et al., 1993, p. 263). A thin section of one of the drilling pebbles of this lithology (144-875C-12M-2, $7-20 \mathrm{~cm}$ ) contains a revealing contact between the gastropod wackestone and a skeletal packstone typical of MIMSP. The wackestone is discolored at the contact, which forms an arc of about $120^{\circ}$ enclosing the wackestone. The surface of the wackestone is ragged and truncates grains. A small vug within the wackestone is filled with the skeletal packstone (Fig. 10). The wackestone is almost certainly a lithoclast, lithified and leached to form molds and vugs before deposition with the skeletal sand of the packstone.

The large cylinder of gastropod mudstone (interval 144-875C$12 \mathrm{M}-2,21-30 \mathrm{~cm}$ ) that forms much of the muddy interval contains large ovoid cavities filled with typical packstone, plus some mud and gastropods (Premoli Silva, Haggerty, Rack, et al., 1993, p. 268, fig. $10)$. These cavities were interpreted as large open burrows infiltrated by the overlying packstone. It now seems more likely that this interval is also a lithoclast with large vugs nearly filled by the surrounding skeletal sand. Large voids are more likely to remain open in a lithified matrix. Molds of the gastropods indicate lithification and leaching sometime in the rock's history. This probably coincided with formation of the vugs, which occurred before lithification and leaching of the enclosing packstone. An interval of dense, well-lithified cobbles, or possibly a single boulder masticated by drilling, could explain the spike in the drilling rate at $110.5 \mathrm{mbsf}$ "... that speculatively coincides with the mudstone layer" (Premoli Silva, Haggerty, Rack, et al., 1993, p. 266).

A sample of laminated muddy wackestone from Hole $876 \mathrm{~A}$ (interval 144-876A-11R-2, 44-47 cm) contains a fauna of gastropods, ostracodes, small foraminifers, and unusual echinoderms. This was recognized on board ship as internal sediment within a large stromatoporoid head that was deeply etched, possibly by bioerosion, coated with a thin layer of cement, and filled with muddy sediment. Otherwise, it would surely have been correlated with the similar muddy lithologies in Hole 875C. Now it seems likely that the stromatoporoid head and muddy fill, which contrast so sharply with the adjacent skeletal packstone, is another large lithoclast. If so, it may correlate after all with the muddy interval in Hole $875 \mathrm{C}$ (interval $144-875 \mathrm{C}-12 \mathrm{M}-2,15-33 \mathrm{~cm}$ ) now interpreted as lithoclasts.

\section{UPPER POROUS SKELETAL CALCARENITE (UPSC)}

The major portion of the limestone of the outer perimeter ridge is white (10YR $8 / 2)$, highly porous, lightly cemented, skeletal packstone and grainstone. This unit extends beneath a thin manganese crust at the seafloor to $105.5 \mathrm{mbsf}$ in Hole $875 \mathrm{C}$ and $98 \mathrm{mbsf}$ in Hole 876A. It is entirely Maastrichtian in age.

The UPSC is uniformly coarse skeletal sand. Small variations in grain size and mud content define packstone $(60 \%$ of all samples examined in thin section), grainstone $(28 \%)$, rudstone $(8 \%)$, and
Table 2. Nonskeletal components as a percentage of bulk volume for Holes $875 \mathrm{C}$ and $876 \mathrm{~A}$.

\begin{tabular}{lcrrrrr}
\hline & & & & & & \\
& & Mud & Peloids & Cement & Porosity & $\begin{array}{c}\text { Secondary } \\
\text { porosity }\end{array}$ \\
\hline $\begin{array}{l}\text { Hole 875C: } \\
\text { UPSC }\end{array}$ & Mean & 2.7 & 2.2 & 5.7 & 38.7 & 35.9 \\
$N=19$ & SD & 3.0 & 2.5 & 3.5 & 10.2 & 19.9 \\
MIMSP & Mean & 30.0 & 2.0 & 2.5 & 9.0 & 33.3 \\
$N=2$ & SD & 7.1 & 1.4 & 0.7 & 4.2 & \\
LPSC & Mean & 8.8 & 0.6 & 16.1 & 19.5 & 72.9 \\
$N=8$ & SD & 18.1 & 1.8 & 13.5 & 13.0 & 36.2 \\
Hole 876A: & & & & & & \\
UPSC & Mean & 3.5 & 1.9 & 7.3 & 36.5 & 37.3 \\
N $=27$ & SD & 4.2 & 3.7 & 3.8 & 8.5 & 29.7 \\
MIMSP & Mean & 10.8 & 12.5 & 26.2 & 6.2 & 62.2 \\
$N=13$ & SD & 14.5 & 15.4 & 11.5 & 5.1 & 36.5 \\
LPSC & Mean & 5.9 & 0.5 & 9.8 & 31.4 & 32.5 \\
$N=8$ & SD & 5.1 & 0.9 & 4.6 & 9.0 & 26.6 \\
Holes 875C and $876 A:$ & & & & & \\
USPC & Mean & 3.2 & 1.1 & 6.7 & 37.4 & 36.9 \\
$N=46$ & SD & 3.7 & 2.9 & 3.7 & 9.2 & 26.7 \\
MIMSP & Mean & 13.4 & 11.1 & 23.0 & 6.6 & 60.0 \\
$N=15$ & SD & 15.2 & 14.7 & 13.5 & 5.0 & 35.8 \\
LSPC & Mean & 7.3 & 0.3 & 12.9 & 25.4 & 52.7 \\
$N=16$ & SD & 12.9 & 0.7 & 10.3 & 12.4 & 37.0 \\
\hline
\end{tabular}

Note: Secondary porosity $=$ percentage of total porosity, $N=$ number of samples, and $\mathrm{SD}=$ standard deviation.

floatstone (3\%). Skeletal components are dominantly the "big three" of all units: mollusks $(33.4 \% ; 20.3 \%$ recognizable as rudists), benthic foraminifers $(22.4 \%)$, and red algae $(19.9 \%)$. Echinoderms $(8.2 \%)$ and corals $(6.4 \%)$ are relatively important. Minor constituents are calcareous sponges, mostly stromatopotoids, $(2.0 \%)$ and dasyclad algae $(0.2 \%)$. Planktonic foraminifers $(0.3 \%)$ occur throughout the unit, mixed with benthic foraminifers in interparticle pores and with mud in skeletal cavities.

Nonskeletal components include peloids, probably completely micritized skeletal grains, that make up $1.1 \%$ of the bulk volume. A few intraclasts are widely scattered through Hole 876A. Mud content is $3.2 \%$, somewhat less than reported in the Initial Reports (Premoli Silva, Haggerty, Rack, et al., 1993, p. 266) because an attempt was made to distinguish matrix mud from the hollow micrite envelopes that represent leached skeletal grains (Fig. 11). However, the mud is so widely distributed that packstone with very small mud content is the dominant lithology, rather than grainstone as indicated by core descriptions. No sedimentary structures were recognized anywhere in this unit.

Extremely high porosity is a striking feature of USPC (Figs. 11, 12). The mean porosity in 22 analyses was $39.4 \% \pm 6.3 \%$. About $24.9 \%$ is primary intergranular and $14.5 \%$ is secondary, mostly skeletal molds. Larger scale dissolution porosity, probably large vugs, are indicated by etched, yellow-stained (by iron oxides?), cement-lined surfaces on contiguous core pieces (e.g., at 144-876A-1R-1, $43 \mathrm{~cm}$ ). These pieces were probably separated by a cavity larger than core diameter. Much of the drilling disturbance (rollers and drilling pebbles) may have been caused by such cavities. No abrupt drops of the drill string were encountered, like those noted in drilling Cretaceous limestones of the Blake Plateau on DSDP Leg 44 (Enos and Freeman, 1978); this indicates that no large caverns with vertical dimensions in meters were penetrated.

Cement has done little more than "spot weld" grains and micrite envelopes in place (Figs. 11 and 12). It forms $6.7 \%$ of the bulk volume, almost entirely in primary pore space; less than $1 \%$ occurs in molds. Most of the cement is very finely crystalline to medium crystalline crusts of limpid, bladed crystals with acute pyramidal terminations and uniform extinction (Fig. 7). Minor quantities of limpid, equant calcite occur as syntaxial overgrowths on echinoids, bivalves, and foraminifers. 
Figure 4. Variation of skeletal components with depth from Holes $875 \mathrm{C}$ and $876 \mathrm{~A}$. USPC, MIMSP, and LSPC bars are the average values for the upper porous skeletal calcarenite, middle indurated muddy skeletal packsone, and lower porous skeletal calcarenite, respectively. Data for Hole 875C are thin-section point counts by Philippe Ebren and estimates from sample set SEDB by Paul Enos. Hole 876A data combine thin-section estimates from aboard ship (by T.M. Quinn, L.F. Jansa, and Paul Enos) and from sample set SEDB (by Paul Enos).

\section{A}

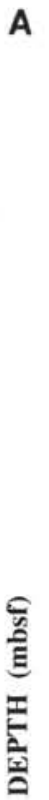

\section{MANGANESE-IMPREGNATED PELAGIC LIMESTONE}

Laminated manganese oxide encrusts the upper surface of the skeletal calcarenite (UPSC) and extends stromatolitic dendrites into an overlying veneer of lithified pelagic limestone (Figs. 13 and 14). The pelagic limestone consists of planktonic foraminifers, nannofossil mud, and bioclasts, including rudist fragments, reworked from the underlying calcarenite. The pelagic cap is only 8 to $14 \mathrm{~cm}$ thick, but within it four microfossil faunules have been differentiated. Ages range from late Paleocene ( 59 m.y.) to late Eocene (Watkins et al., this volume).

The manganese-encrusted contact was recovered in two large pieces that were probably in proper sequence and orientation from Hole $875 \mathrm{C}$ (interval 144-875C-1M-1, 0-14 cm). These could represent two distinct crusts or one could be a clast displaced on the seafloor. Two drilling pebbles of manganese crust were recovered from Hole 876A (interval 144-876A-1R-1, 0-8 cm). The most informative recovery from the contact was interval $144-876 \mathrm{~A}-1 \mathrm{R}-1,22-41 \mathrm{~cm}$. A vertical, manganese-stained contact extends from near the top of the piece at 0.25 to $0.39 \mathrm{mbsf}$ where it abruptly flattens and passes out of the core (Premoli Silva, Haggerty, Rack, et al., 1993, p. 266, fig. 9). Maastrichtian skeletal packstone with phosphatized matrix and patchy manganese stain is in vertical contact with lithified pelagic limestone laced with dendrites of manganese oxide. No unequivocal borings,

\section{Hole 875C}

RED ALGAE

GREEN ALGAE

- PLANKTONIC FORAMS

$\because$ BENTHIC FORAMS

CORALS

$\$$ RUDISTS

2 MOLlusk fragments

$\$$ Gastropods

¿ OSTRACODES

ECHINODERMS

$\because \quad$ UNKNOWN/MICRITIZED

MISCELLANEOUS SKELETAL truncated grains, or skeletal encrustations were visible on the contact, but the vertical orientation demonstrates that the skeletal packstone was lithified and eroded before deposition of the pelagic ooze. The matrix of the packstone is nannofossil mud with planktonic foraminifers of Eocene age (Watkins et al., this volume). Pelagic mud fills the interparticle pore space and a few skeletal molds near the contact, but planktonic foraminifers were filtered out by pore-throat constrictions within a few centimeters of the contact. The mud is gradually reduced to perched deposits on grains and in cavities that occupy $3 \%$ bulk volume at $67 \mathrm{~cm}$ below the uppermost contact $(0.75 \mathrm{mbsf})$. The matrix is pervasively replaced by phosphate to $48 \mathrm{~cm}$ below the contact $(0.56$ mbsf) and patchily replaced at greater depths. No comparable infiltrated matrix was recognized in grainstones recovered below the crusts at Site 875 , but some of the copious planktonic foraminifers cemented into the upper part of the skeletal calcarenite (interval 144-875B-1R-1, 9-13 cm) may have infiltrated from the contact.

\section{INTERPRETATIONS}

As a first approximation, the outer perimeter ridge originated as a huge pile of skeletal sand. Age relationships, now more clearly in focus than was possible for the Initial Reports volume, place constraints on the history of sedimentation that formed the outer ridge. The basis for age assignments is presented in detail by Erba et al. (this volume). In 
B

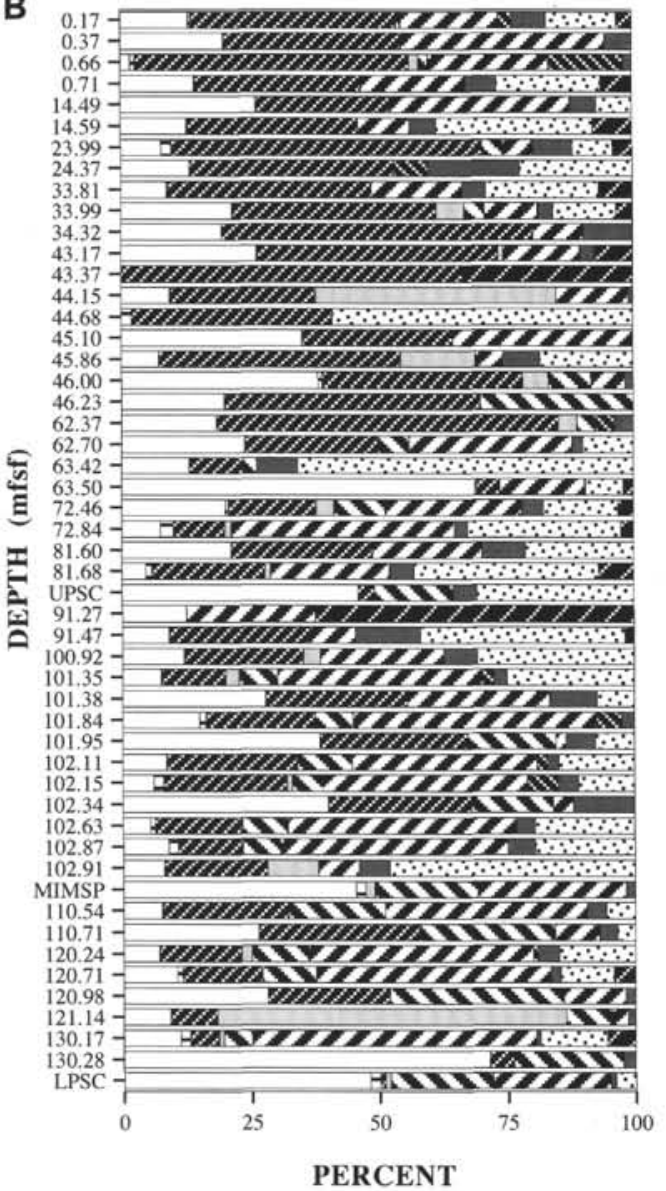

Hole 876A

RED ALGAE

GREEN ALGAE

$\exists$ PLANKTONIC FORAMS

$\approx$ BENTHIC FORAMS

CORALS

$\$$ RUDISTS

2 MOLLUSK FRAGMENTS

M GASTROPODS

(C) OSTRACODES

ECHINODERMS

$\therefore$ UNKNOWN/MICRITIZED

MISCELLANEOUS SKELETAL brief, the Campanian episode of sedimentation now documented at Sites 873,874 and 877 appears to be lacking on the outer perimeter ridge. Campanian benthic foraminifers of the Pseudorbitoides assemblage are present at the base of Hole 875C (Sample 144-875C-14M-1, $59 \mathrm{~cm}$ ) and Hole 876A (I. Premoli Silva, pers. comm., 1994), but they are mixed with the benthic foraminifer Omphalocyclus, considered a Maastrichtian index. Thus, the Campanian fossils are apparently reworked, presumably from the inner perimeter ridge. If the lowest occurrence of Omphalocyclus is used to correlate between sites, the base of Holes $875 \mathrm{C}$ and $876 \mathrm{~A}$ would correlate with the uppermost units from Site 873 (about 65 mbsf or $1400 \mathrm{mbsl}$ ) and from Site 877 (about $5 \mathrm{mbsf}, 1360 \mathrm{mbsl}$ ). Omphalocyclus was not detected at Site 874. (The "questionable occurrence" in interval 144-874B-5R-2, 60-64 cm, reported in Premoli Silva, Haggerty, Rack, et al., 1993, p. 227, was not confirmed.) The common large benthic foraminifer, Sulcoperculina, extends to the top of the lithified carbonate section at Sites 873,874, and 877. Sulcoperculina is absent in Hole $875 \mathrm{C}$ from interval 144875C-3M-1, 65-67 cm (18.17 mbsf) and above and in Hole 876 A at interval 144-876A-4R-1, 69-76 cm (34.06 mbsf) and above. As associated forms such as Asterorbis continue to the top of the sequence, the absence of Sulcoperculina is taken to indicate that at least the upper $18-34 \mathrm{~m}$ of skeletal calcarenite in the outer perimeter ridge is younger than any of the carbonate rocks of the inner perimeter ridge and lagoon. The absolute age is about 68 m.y. (late Maastrichtian; Erba et al., this volume). Thus, the outer perimeter ridge was indeed plastered on an inner perimeter ridge that is 1 to $2 \mathrm{~m} . \mathrm{y}$. older (69-70 m.y.), but not as a nested reef ridge. The apparent lithologic correlation of the skeletal calcarenites of the outer ridge with nearly identical calcarenites at the base of the inner ridge (Subunits IIF, IIE, and IID, Site 874, and Subunits IIE and IID, Site 877) reflects comparable depositional regimes (i.e., facies equivalence rather than age equivalence).
Figure 4 (continued).

\section{Origin of Sediment}

The component composition of the skeletal calcarenites points to derivation from the platform-margin carbonate "factory" as particulate detritus. Most of the very coarse, cobble-sized fractions and very fine, mud-sized fractions were removed in transport. The very fragile appearance of the skeletal grains is deceptive; they became fragile by extensive leaching in situ. They were young, robust skeletal fragments during deposition.

The shape of skeletal grains is a notoriously poor index of the amount of transport or reworking. They may be round because the organism was round, although abrasion that truncates ornamentation or wall structure can generally be detected in thin section. Conversely, angularity may actually increase with abrasion because skeletons tend to split along internal zones of weakness, as originally pointed out by H.C. Sorby and demonstrated by R.L. Folk as the "Sorby effect" (Folk, 1967; Folk and Robles, 1964). The Sorby effect is evident in Wodejebato samples, notably in radiolitid rudist fragments that are typically angular. Considerable abrasion is also evident on most skeletal fragments of the outer perimeter ridge, although the unabraded rhodoliths (Fig. 8) and some other encrustations probably developed in situ. No rudists seem to be in growth position so as to represent a local source.

\section{Formation of the Outer Perimeter Ridge}

How were the grains assembled in the outer perimeter ridge? What is the origin of the positive relief and of the trough that separates the perimeter ridges? Is it tectonic, depositional topography, or erosional modification? Concentric perimeter ridges appear intermittently along the north and west margins of Wodejebato Guyot (Bergersen, this volume) so any explanation has general implications. 


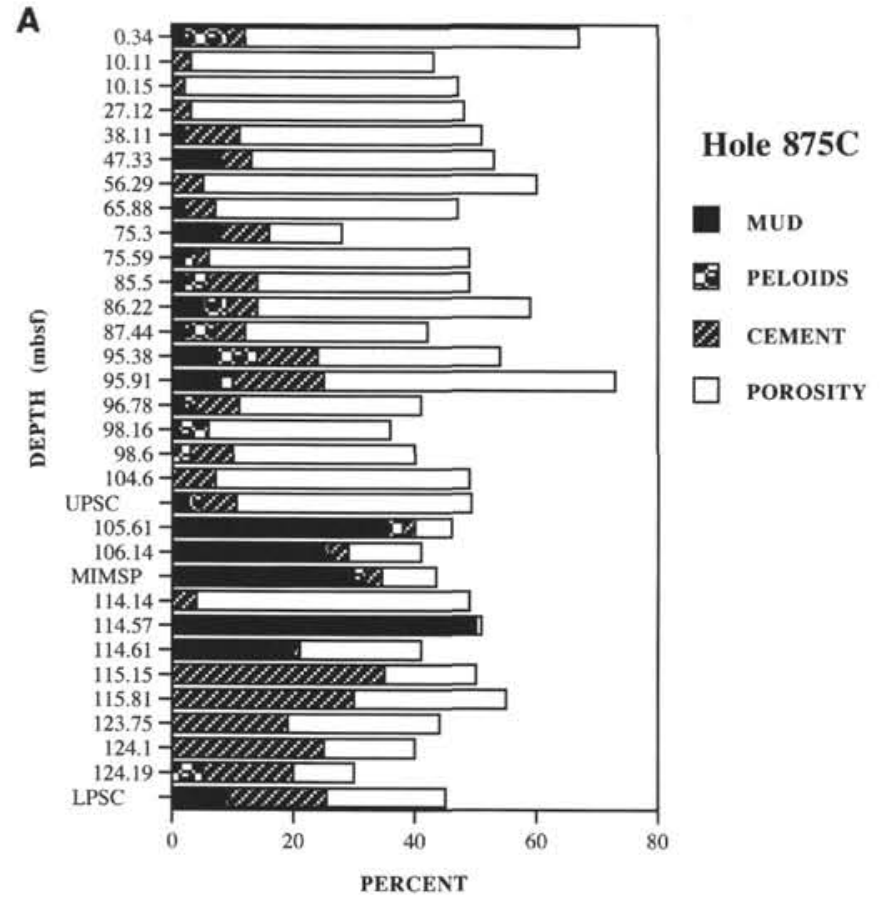

Figure 5. Downhole variations in non-skeletal components, mud, peloids, cement, and porosity from Holes $875 \mathrm{C}$ and $876 \mathrm{~A}$. Peloids include grains aitered beyond recognition of origin and fecal pellets. USPC, MIMSP, and LSPC bars are the average values for the upper porous skeletal calcarenite, middle indurated muddy skeletal packsone, and lower porous skeletal calcarenite, respectively. Based on thin-section estimates from shipboard and shore-based studies.

There is no hint of a fault or slump separating the parallel ridges from the seismic traces (Fig. 2; see Bergersen, this volume).

Depositional topography as the origin of the outer perimeter ridge would imply lateral transport for up to $3 \mathrm{~km}$ to produce a spitlike feature (Fig. 1). Such a scenario would be consistent with the general southeasterly slope of the surface. Unfortunately no seismic profiles were run along the axis of the ridge, so the internal geometry is unknown. The degree of washing, sorting, and abrasion of the grains points to considerable reworking, probably by waves or currents in shallow water. Deposition directly from the factory would not produce this degree of sediment modification.

The spit scenario has some consequences for the history of Wodejebato. Spits grow in the surf zone. Beach drift is a major component of their development. This would imply that the outer perimeter ridge developed in pace with one or several prolonged rises in sea level, beginning perhaps as a low-stand wedge and developing as a transgressive system tract, in the jargon of sequence stratigraphy. Development of a spit near the top of the seaward slope of an atoll seems anomalous; spits typically develop on platform tops where refraction and shoaling control the open-ocean surf. However, a surf zone backed by an island, the present inner perimeter ridge, and an embayment, perhaps the present inter-ridge trough, would be more compatible and is consistent with a lower stand of sea level. The present depth of the trough would result mainly from the buildup of the ridge.

What was the factory that produced this considerable volume of sediment? Was it reefs at a level lower than the inner ridge, somewhere northwest along the atoll perimeter? If the inner ridge itself was the source, the skeletal sands surrounding the reefs, exposed by lowered sea level, would have to remain unconsolidated and susceptible to erosion as discrete particles through a considerable period of exposure. Exposed carbonates become cemented (or dissolved) very rapidly, in time spans measured in years to a few tens of thousands of

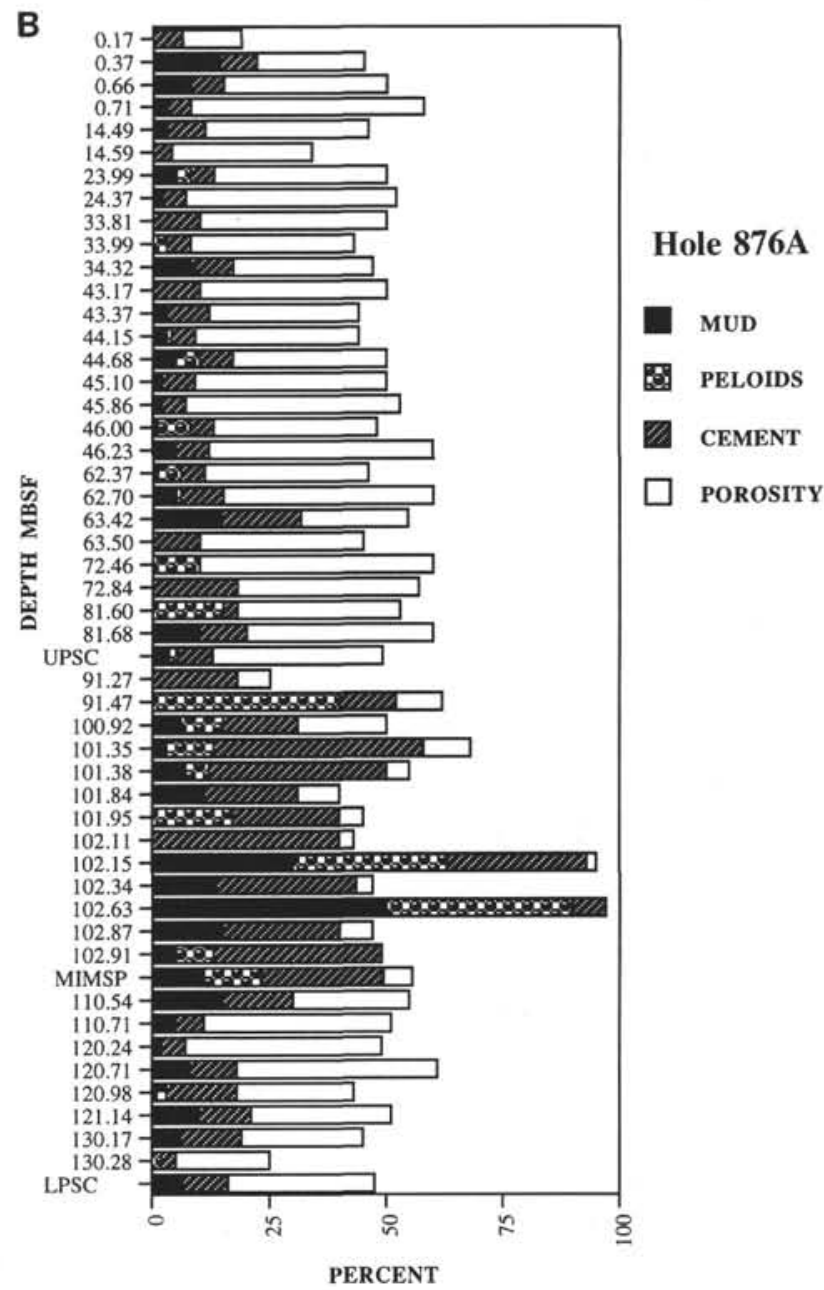

Figure 5 (continued).

years (Lafon and Vacher, 1975; Vacher et al., 1990). The spit hypothesis is attractive and has some important consequences that are ultimately testable, although perhaps not with the present data.

An alternate hypothesis, mentioned but not developed in the Initial Reports volume (Premoli Silva, Haggerty, Rack, et al., 1993, p. 269 ), is that the trough postdates deposition as an erosional event which is primarily responsible for the isolation and relief on the outer ridge. In this scenario, the outer ridge once formed a continuation of the seaward slope of the inner perimeter ridge. In some profiles such a slope is easily visualized (cf. Fig. 2, especially $A-A^{\prime}$ and $G-G^{\prime}$ ); in others, it is clear that such a slope would not have a smooth profile (cf. Premoli Silva, Haggerty, Rack, et al., 1993, p. 217, fig. 5, profile $\mathrm{C}-\mathrm{C}^{\prime}$, perhaps $\mathrm{B}-\mathrm{B}^{\prime}$ and $\mathrm{E}-\mathrm{E}^{\prime}$ ).

The sediment preserved in the outer ridge would have been transported directly down the slope from the rudist-dominated shoals. Reworking by waves in shallow water before transport could probably account for the size, sorting, and abrasion characteristics of the sediment outlined above. If transport was directly down the slope, it is surprising that no blocks of reef debris were encountered at Sites 875 or 876 . The present slopes, $1.6^{\circ}$ to $7.2^{\circ}$ on the upper slope and $3.7^{\circ}$ to $15.3^{\circ}$ on the lower slope (Bergersen, this volume), are certainly adequate to move debris by any of several mechanisms, such as storm surge, gravity creep, debris flow, or turbidity currents. The lower slope would have been subsequently steepened by the erosional event, but the unaltered upper slopes would have been adequate. The degree of rigidity developed by rudist banks or reefs has been the subject of some controversy (Kauffman and Sohl, 1974); however, they do produce copious megabreccias (Enos, 1977a; Enos and Stephens, 


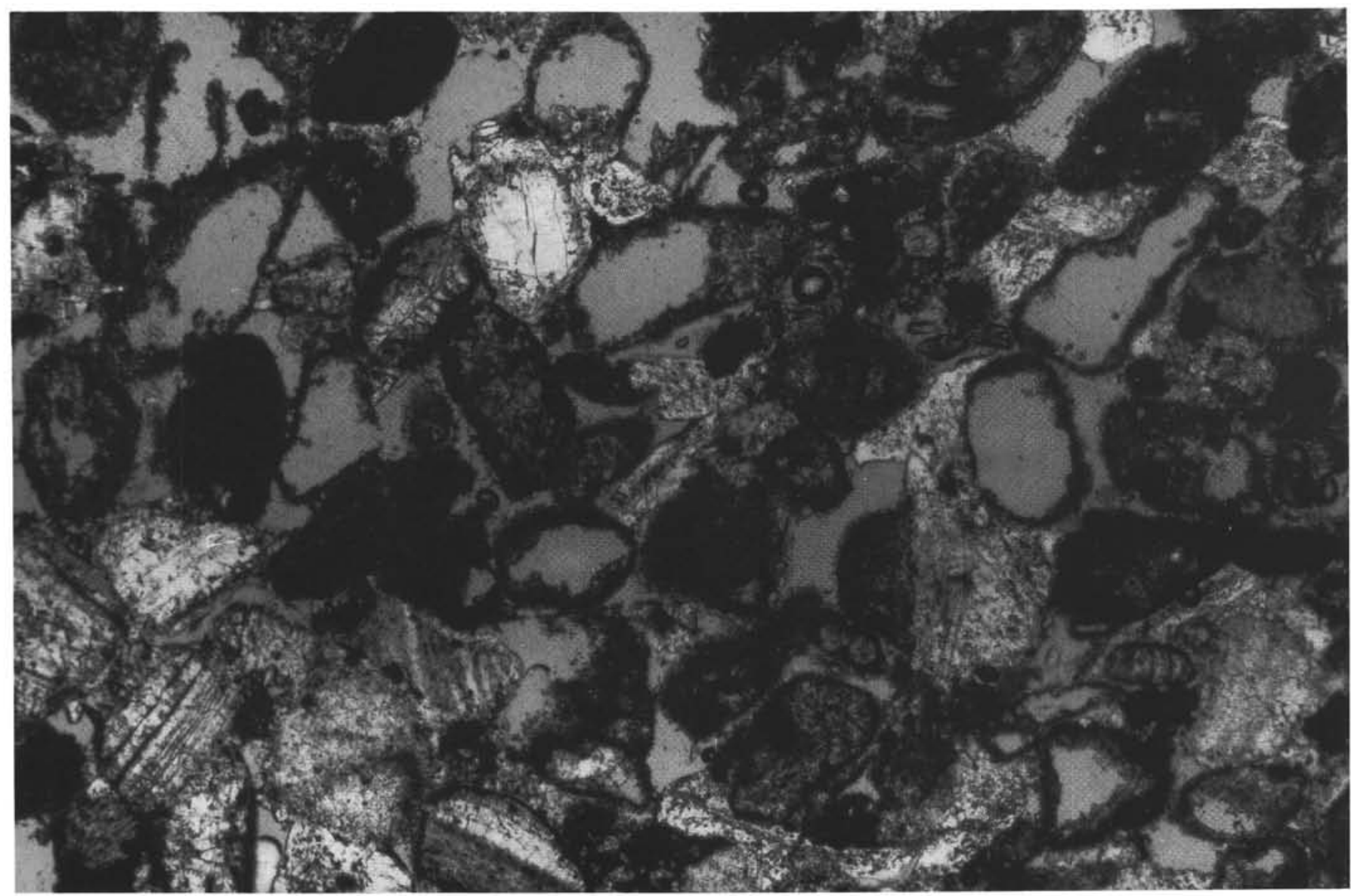

Figure 6. Molds, probably of abraded skeletal grains, framed by micrite envelopes. Cementation is by very finely crystalline, by limpid calcite (scarcely visible at this scale), and by limpid syntaxial overgrowths (black arrow). Several planktonic foraminifers are in the interstices (white arrows). Photomicrograph, plane light. Sample $144-875 \mathrm{C}-14 \mathrm{M}-1,26-28 \mathrm{~cm}$. Maximum dimension is $3.2 \mathrm{~mm}$.

1993). If the degree of rigidity is controversial in surface exposures, it can scarcely be settled from limited core recovery on the inner perimeter ridge of Wodejebato. It is clear that penecontemporaneous submarine cementation was extensive in many intervals at Sites 874 and 877 (Camoin et al., this volume). Early lithification is also demonstrated by an interval of intense boring by lithophagous bivalves from Hole 877 (interval 144-877A-5R-3, 57-55 cm). There seems little doubt of the potential to produce blocks on the inner perimeter ridge. The only lithified blocks that were recognized in the outer perimeter ridge are of quite different facies in interval 144-875C$12 \mathrm{M}-2,15-33 \mathrm{~cm}$ (see previous discussion of MIMSP and conclusions below). Of course, it was this contrast that led to their ultimate recognition as blocks. It is possible that blocks of skeletal calcarenite went unrecognized, but no examples of marine cementation were encountered at Sites 875 or 876 , except for four samples from the middle unit (MIMSP) in Hole 876A. The few puny, rounded lithoclasts recognized in thin sections do not figure in the search for reef blocks.

The erosional event itself must also be considered. The floor of the trough is between 90 and $110 \mathrm{~m}$ below the crest of the adjacent inner perimeter ridge (Fig. 1; in Fig. 2, a relief of only $50-80 \mathrm{~m}$ is indicated as different survey systems were used). If subaerial erosion produced the trough, a minimum lowering of sea level of $90 \mathrm{~m}$ is required. Nothing is known of the timing of the erosion, but if it were subaerial it would have to precede drowning of the atoll, possibly in the late Maastrichtian (ca. 70.5 m.y.; Wilson et al. and Erba et al., both in this volume), certainly by the late Paleocene (Watkins et al., this volume). The closed depression, 10-30 m deep, in the floor of the trough, if subaerial in origin, indicates dissolution as the major agent of erosion.
Stream erosion on a young carbonate island is unlikely in any case; drainage is invariably by infiltration and ground-water discharge through the highly permeable carbonates. The orientation and morphology of the trough would indicate a large dolina parallel to the margin of the atoll. Karst features typically follow fractures; fractures parallel to adjacent slopes are common features of carbonate platforms (Newell and Rigby, 1957, p. 29). See below ("Diagenetic Environments") for time constraints.

Submarine erosion can also produce valleys, up to the scale of submarine canyons, and could conceivably have operated at any time in the history of the guyot. However, erosion in submarine valleys results from transport of sediment. Both the production of sediment and mechanisms for funneling it into a submarine canyon require a shallow atoll, not a drowned guyot. Attendant erosion would be constrained between middle or late Maastrichtian and pre-late Paleocene, or possibly to late Maastrichtian. Two other features besides time militate against submarine erosion. Closed depressions are very unusual in submarine valleys; a graded profile is the norm. The orientation parallel to slope would also be highly anomalous; fault control would be indicated, and faults seem to be lacking. The morphology of the trough even has some features of a small cirque (Fig. 1); alpine glaciation early in the history of Wodejebato Atoll would qualify as an outrageous hypothesis.

Both the subaerial erosional hypothesis and the constructional hypothesis seem admissible to explain the morphology of the outer perimeter ridge. The age and geometric relationships between the inner and outer perimeter ridge indicate progradation of the atoll margin to produce the outer ridge as a highstand systems tract, after accretion of 


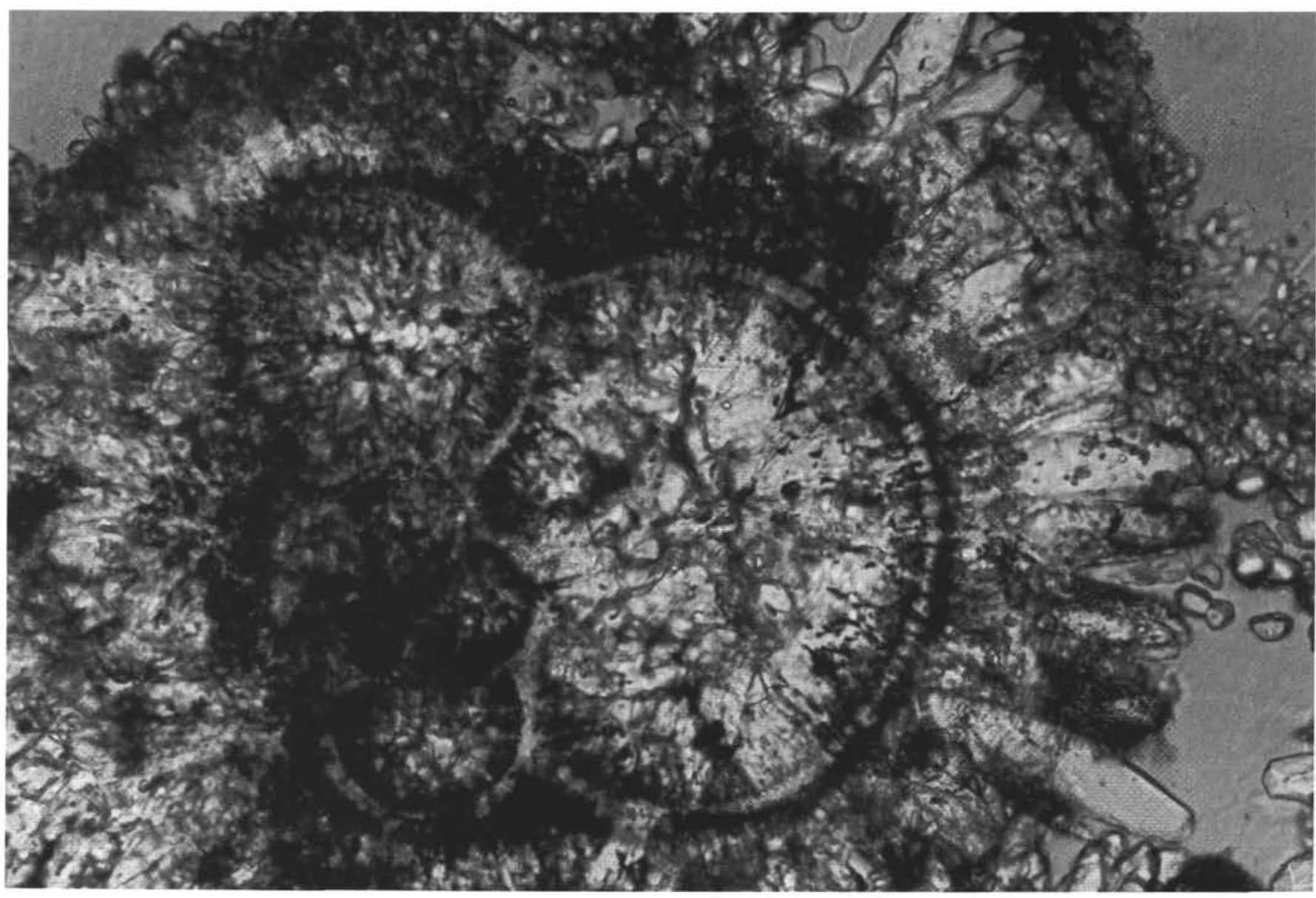

Figure 7. Pyramidal crystals of limpid calcite (PLUC) form a crust in interparticle pores and fill the test of a planktonic foraminifer. Photomicrograph, plane light. Interval 144-876A-8R-1, 94-100 cm. This sample from the upper calcarenite (UPSC) illustrates the most common cement in all units. Maximum dimension is 0.42 mm.

the inner perimeter ridge. The subsequent erosion hypothesis would fit a more traditional sequence-stratigraphic model of eustatic lowering of sea level. However, lateral accretion of a spit could also be a highstand systems tract, although a transgressive origin appears more likely (see above). This serves to emphasize that sequence stratigraphy deals with stratal geometry, not with mechanisms. Either hypothesis poses some problems and each has some interesting consequences. In the balance, the constructional hypothesis appears more plausible.

\section{Depositional Environments}

Recognition that the middle muddy interval (MIMSP) contains lithoclasts with dissolution porosity developed before resedimentation indicates an episode of erosion in a more restricted part of the guyot. Intervals of skeletal wackestone or mudstone bearing a restricted fauna of gastropods, ostracodes, and discorbid and miliolid foraminifers from the upper part of Holes 874B and 877A (intervals 144-874B-2R$2,76-79 \mathrm{~cm}$, and $-6 \mathrm{R}-1,8-10 \mathrm{~cm}$, and intervals $144-877 \mathrm{~A}-1 \mathrm{R}-2$, $10-14 \mathrm{~cm}$, and $-3 R-1,38-123 \mathrm{~cm}$ ) seem the best facies matches. These muddy intervals in the inner perimeter ridge are now considered older than the intervals bearing muddy lithoclasts in MIMSP, so lithification and dissolution before erosion is reasonable. The depositional milieu of these lithoclasts is one with some mud accumulation and with the only example of submarine cementation recognized in the outer ridge. These conditions probably reflect reduced rates of sediment accumulation (Premoli Silva, Haggerty, Rack, et al., 1993, p. 269). The middle limestone is also distinguished by containing numerous rhodoliths. These nodular algal encrustations occur in very shallow water, but they may be more characteristic of gentle slope environments with slow sedimentation rates (Adey and Macintyre, 1973). This is the only setting where they are known in the Holocene of south Florida, for example (Ginsburg, 1956; Enos, 1977b). If the blocks were shed by subaerial erosion during a lowstand of sea level, the reduced area of carbonate production on the slope as compared to the atoll top would explain a slowdown in sedimentation. If the erosion reflects a period of incipient drowning, both decreased sediment production and increased depth would tend to retard sedimentation.

The significance of the inclined stratification in the muddy pellet packstone within MIMSP (interval 144-876A-11R-1, 135-140 cm) is enigmatic. The inclined, millimeter-scale, coarse-fine lamination with mud drapes and tiny reactivation surfaces suggests tidal action, or other current regime with regular and appreciable fluctuations. The pellet and mud lithology is also consistent with a low-energy tidal setting. Less probable interpretations would be inclined beds of a low-energy beach or even internal sedimentation within a cavity system. Such sweeping conclusions cannot be justified from a single 5 -cm sample amid limited recovery, but neither can the possibilities be ignored. It is part of the record and is demonstrably in stratigraphic sequence. It could, of course, be a lithoclast; several clasts are recognized in this interval. This would merely displace the problem. This lithology is unique among those recovered from Wodejebato Guyot.

\section{Significance of Planktonic Foraminifers}

Planktonic foraminifers have now been identified in virtually all levels of Holes $875 \mathrm{C}$ and $876 \mathrm{~A}$. None are shown above interval 


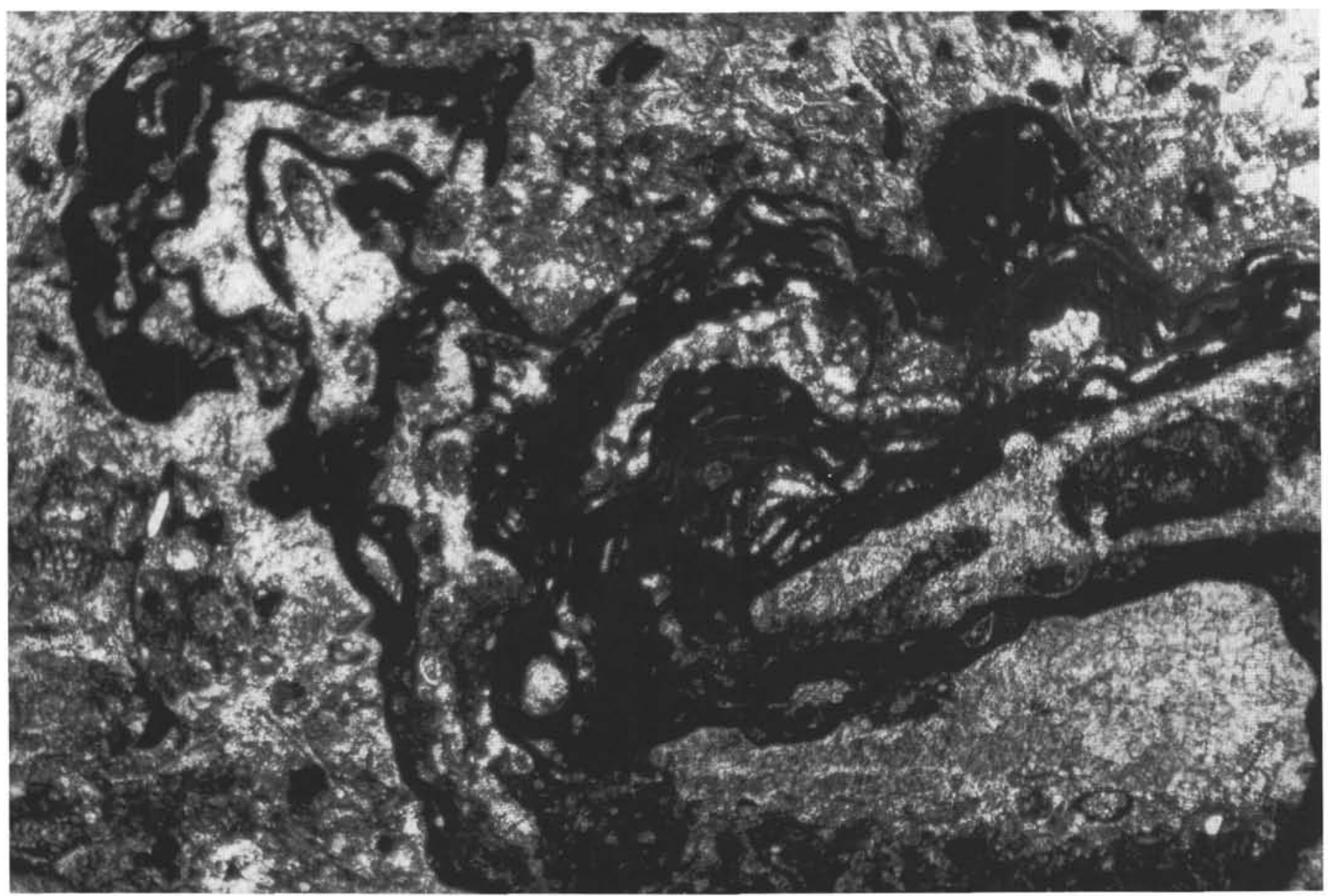

Figure 8. Detail of a rhodolith, consisting mainly of coralline algae (dark), but including foraminifers and other unidentified taxa, as well as muddy sediment and molds of skeletons. Photomicrograph, plane light. Interval 144-876A-11R-1, 104-112 cm. Maximum dimension is $8 \mathrm{~mm}$.

144-875C-4M-1, 2-5 cm, in the Initial Reports volume (Premoli Silva, Haggerty, Rack, et al., 1993, p. 271), but they are abundant in interval $144-875 \mathrm{C}-1 \mathrm{M}-1,7-10 \mathrm{~cm}$. These are conceivably Tertiary foraminifers, but they were in place before the initial cementation. Planktonic foraminifers are also present in each of 15 thin sections (set SEDB) from the upper calcarenite (UPSC) from Hole 876A, including Cores $144-876 \mathrm{~A}-1 \mathrm{R}$ through $-4 \mathrm{R}$, to fill a gap reported in the Initial Reports volume (Premoli Silva, Haggerty, Rack, et al., 1993, p. 274). Their presence does not constrain the geologic history of the guyot except to provide some general age information. Their greater abundance in the outer perimeter ridge may primarily reflect its position on the windward side of the atoll. It may be relevant that Ginsburg (1956) reported planktonic foraminifers in samples of modern sediment from the south Florida shelf margin only at water depths below $50 \mathrm{~m}$.

\section{Diagenetic Environments}

Diagenetic features also provide some constraints on the history of Wodejebato outer ridge. Skeletal-moldic porosity is extreme throughout the upper and lower calcarenites (UPSC and LPSC; Figs. 6 and 11). Most of the molds likely were formed from original aragonitic skeletons, so far as can be deduced from shapes of micrite envelopes. Such a fragile pore network could only have been developed by dissolution in situ. Minimal compaction, indicated by in situ grain breakage (Fig. 12 ), is supporting evidence. Such extreme fabric-selective dissolution typically develops in meteoric systems from the aggressive dissolution behavior of meteoric waters. A calculation based on thickness, amount of moldic porosity developed, and some assumptions about Late Cre- taceous climate suggest that about $11 \mathrm{~m} . \mathrm{y}$. would be required to develop the observed pore space (Appendix).

An alternative possibility is that dissolution occurred in cold seawater, beneath the thermocline, that was undersaturated with respect to aragonite. A much longer period of time is available for this slower process, essentially the entire Tertiary. The environments responsible for dissolution are generally difficult to ascertain, because material is removed, not added.

The nature of cementation tends to favor the submarine-dissolution alternative. Most of the cements in the skeletal calcarenites are nondescript crusts of pyramidal, limpid calcite crystals with uniform extinction (Opdyke et al, this volume, describe such cement from Site 877 under the acronym PLUC). The remaining cements are syntaxial overgrowths that probably represent the same episode of cementation or a slightly later one. The temperatures of precipitation indicated by oxygen-isotopic analyses of such cements from Site 877 are well below those of tropical surface seawater or meteoric water at low latitudes (Opdyke et al, this volume). Ratios of ${ }^{87} \mathrm{Sr} /{ }^{86} \mathrm{Sr}$ from these cements indicate precipitation from Tertiary seawater, rather than Cretaceous (Wilson et al., this volume). Thus, slow precipitation after drowning of the atoll is indicated.

These cements occur in interparticle pores and in lesser abundance in molds. The precipitation of cement probably coincided at least in part with dissolution to form the molds. This seeming paradox of dissolution of carbonate accompanying carbonate precipitation is explained by the dimorphism of calcium carbonate. The dissolved particles were aragonite, mostly mollusks, as far as can be judged from the outlines of the molds preserved by micrite envelopes and by 


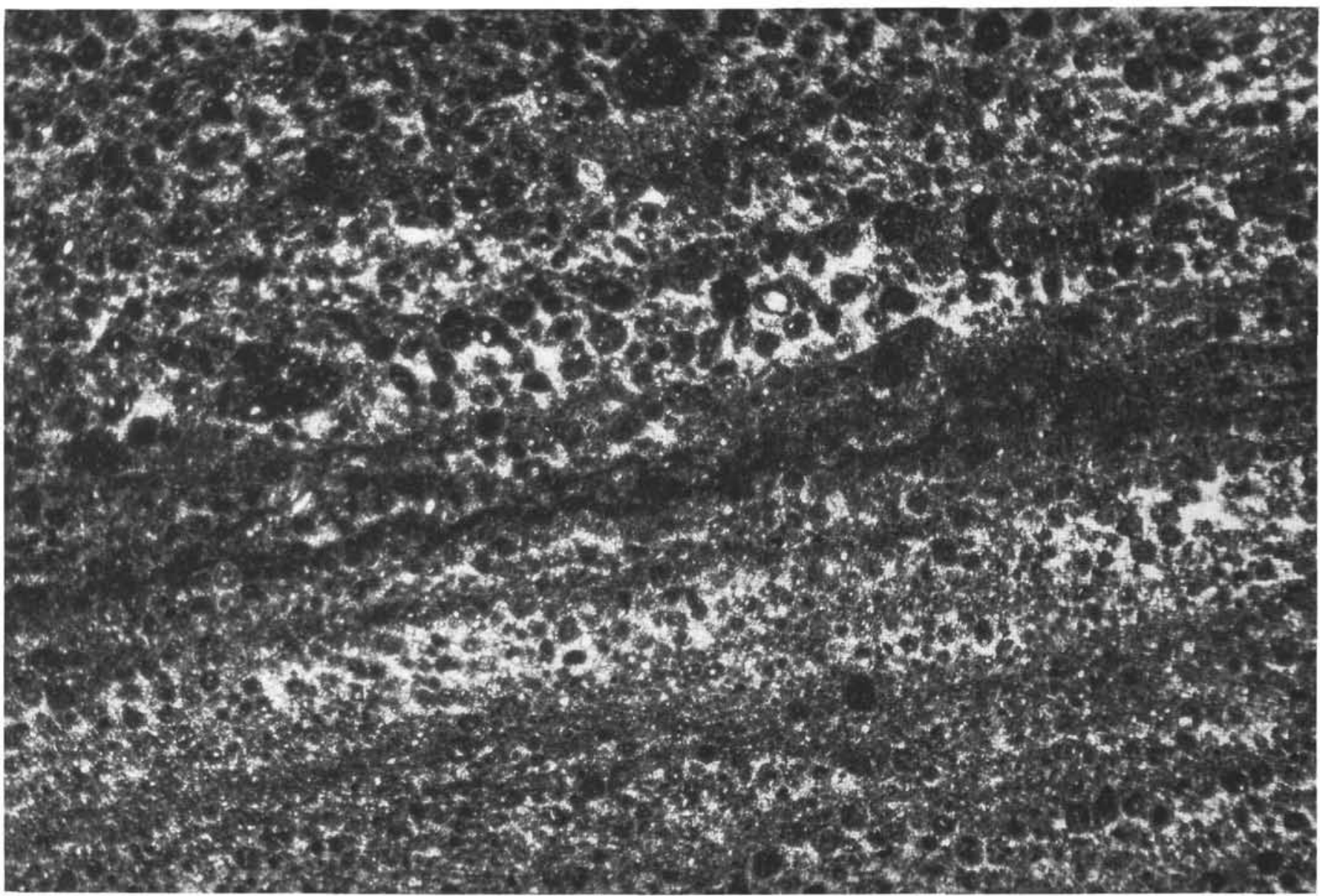

Figure 9. Peloidal sand with millimeter-scale inclined lamination accentuated by drapes of lime mud. Photomicrograph, plane light. Interval 144-875A-11R-1, $135-140 \mathrm{~cm}$. Maximum dimension is $8 \mathrm{~mm}$.

the original mineralogy of the grains that remain. These are benthic foraminifers, echinoderms, and red algae, all composed initially of magnesian calcite, as well as the outer shell layers of radiolitid rudists and the planktonic foraminifers, composed of calcite. Cold, subthermocline seawater is typically undersaturated with respect to aragonite, even in the tropics. Cements precipitated from such waters are calcite, without appreciable magnesium (Schlager and James, 1978). Thus, the same water could dissolve aragonite mollusk grains while cementing them in place and eventually lining the molds with small calcite crystals. This process probably continues at present.

The morphology of the upper surface of the skeletal calcarenites, essentially at the seafloor, presents a much different picture. Relief of about a meter on unconnected depressions in the manganeseencrusted surface of the limestone was seen over a considerable area during seafloor video surveys to select the outer-ridge drilling sites. The vertical contact captured in the core barrel in Hole 876A (Premoli Silva, Haggerty, Rack, et al., 1993, p. 266, fig. 9) indicates additional relief of at least $31 \mathrm{~cm}$ beneath the veneer of pelagic limestone. Details of the vertical contact constrain the timing of events. The surface is carved into late? Maastrichtian limestone and is covered by late Paleocene and Eocene pelagic carbonate. Maastrichtian planktonic foraminifers reported from a few sites suggest that drowning may have occurred before the end of the Cretaceous. Caution is necessary here, however, as planktonic foraminifers had been raining down throughout active deposition on the windward atoll margin (see above). The upper limestone (UPSC) was necessarily lithified before the vertical contact was eroded. The pelagic matrix filtered into a few molds, reflecting early small-scale dissolution. These varied dissolution fea- tures formed the upper surface of the skeletal calcarenite before drowning. This surface is interpreted as microkarst, reflecting exposure to meteoric waters. Such a surface, with $1.3 \mathrm{~m}$ of material removed by dissolution could have developed in half a million years (Appendix).

Alternative explanations exist, such as bioerosion, mechanical erosion, or subsea dissolution. The surface appears too smooth to have been formed by bioerosion. Moreover, no borings, scalloped surfaces, or encrustations were seen. Mechanical erosion, for example by gravity spalling, can create steep slopes and high relief. Site 876 was hundreds of meters from the slope break, however, and no spalled blocks were observed in the seafloor video survey or cores. If gravitational forces removed a block, they would also tend to prevent deposition of the overlying pelagic carbonate. Subsea dissolution, postulated above as a mechanism to form small-scale dissolution features such as molds during the Tertiary, seems ruled out by the short time span between formation of the surface and deposition of pelagic carbonates. Dissolution in meteoric waters is much more rapid.

The surface may have large-scale karst if the inter-ridge trough is a meteoric-dissolution feature (see above). This would require an episode of subaerial exposure of the outer perimeter ridge, and perhaps the inter-ridge trough, before drowning in the late Paleocene or earlier. Meteoric dissolution of the trough might have required 11-24 m.y. (Appendix). This period of time is excessive, given the geologic constraints outlined above that indicate a maximum of 9 m.y. of exposure and possibly less than 2 m.y. (Wilson et al., this volume). This seems to preclude a karst origin for the trough. More extensive subaerial exposure and meteoric circulation would be required to produce the extensive solution porosity encountered throughout the outer 


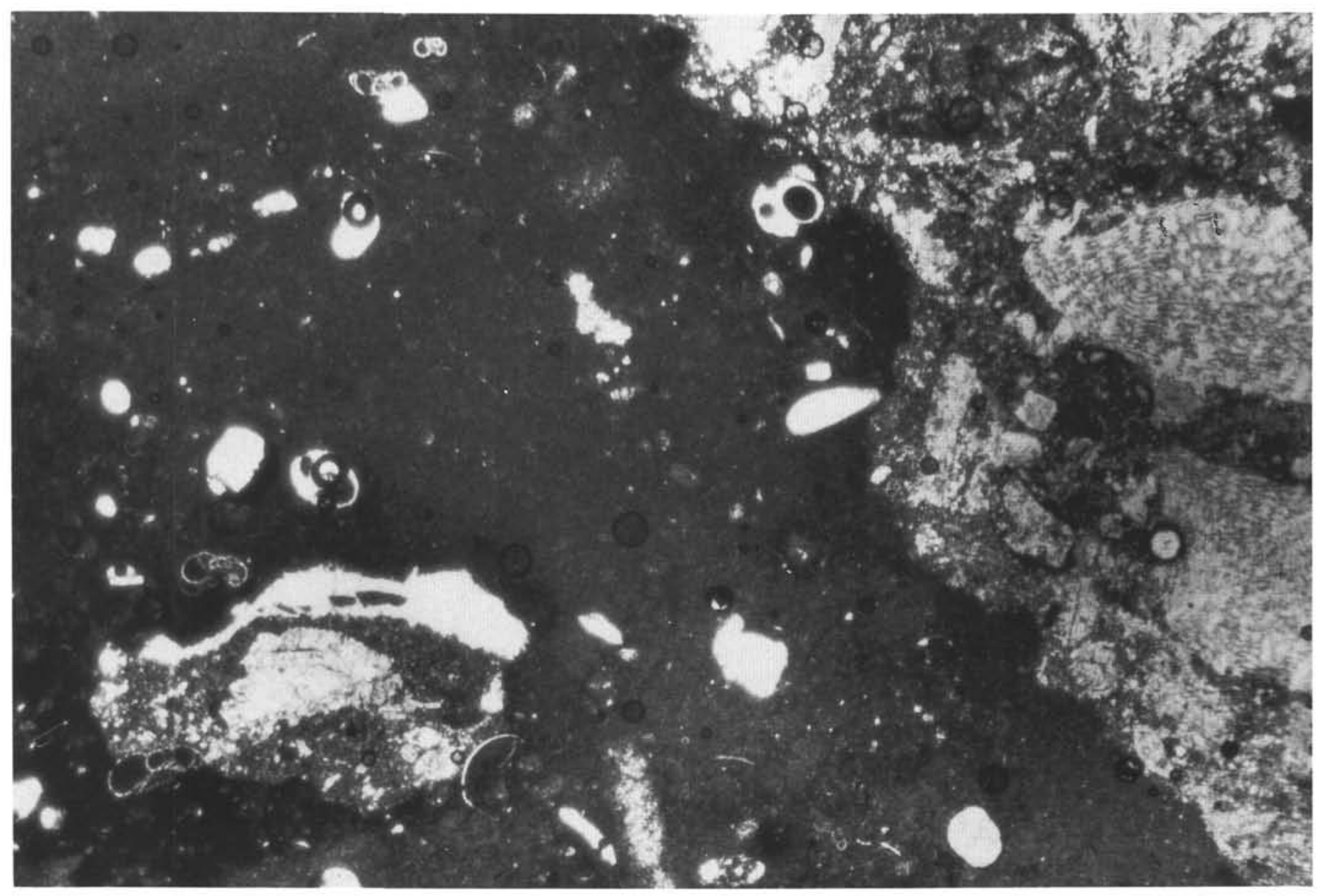

Figure 10. Ragged, slightly stained contact of skeletal wackestone with muddy packstone. Overall, the contact is nearly vertical and convex into the packstone. Small vug (lower left) was infiltrated by sediment resembling the packstone. White areas are microvugs and skeletal molds. The wackestone is interpreted as a lithoclast. Photomicrograph, plane light. Interval $114-875 \mathrm{C}-12 \mathrm{M}-2,7-20 \mathrm{~cm}$. Maximum dimension is $8 \mathrm{~mm}$.

perimeter ridge, an estimated 10.5-11.5 m.y. (Appendix). Subaerial exposure could have been the process that terminated carbonate production, the first step in the ultimate drowning of Wodejebato Guyot. Subsea dissolution is favored for the distributed moldic porosity as outlined above. The time restrictions introduced by the geologic history (cf. Watkins et al., this volume) also indicate that subsea dissolution is required for part of the chemical erosion.

\section{CONCLUSIONS}

The outer perimeter ridge of Wodejebato Guyot comprises three Maastrichtian carbonate units that directly overlie slightly altered basaltic basement: a lower, porous, lightly cemented, skeletal grainstone and packstone (LPSC); a thin middle unit of indurated, muddy, skeletal packstone (MIMSP) containing rhodoliths and leached lithoclasts; and a thick, upper, highly porous, very lightly cemented, skeletal grainstone and packstone (UPSC).

The upper surface of the Maastrichtian limestone has closed depressions with steep relief of more than $1 \mathrm{~m}$, is coated by manganese oxide crusts, and is veneered by late Paleocene to late Eocene pelagic limestone. Pelagic sediment of Eocene, and possibly late Maastrichtian, age has filtered into interparticle and moldic pores at least $67 \mathrm{~cm}$ below the upper surface.

The huge pile skeletal sand that constitutes most of the outer perimeter ridge appears to be entirely Maastrichtian in age, somewhat younger than the base of the inner perimeter ridge. The upper 18-34 $\mathrm{m}$ of UPSC may be younger than any of the platform carbonates of the inner perimeter ridge.

The skeletal sand is composed of rudist and other mollusk fragments, benthic foraminifers, and red algae, with echinoderms, corals, and minor calcareous sponges, dasyclad algae, and planktonic foraminifers. It was abraded and sorted by transport from the platform margin. Extensive leaching and light cementation occurred after deposition.

The outer perimeter ridge is interpreted as a constructional, spitlike feature, formed in very shallow water during a rise in relative sea level. This ridge left a depositional trough in front the slightly higher inner perimeter ridge. An alternative interpretation of the trough is a karst feature eroded into the upper slope apron of the atoll during a lowstand of relative sea level.

Leached lithoclasts, an important component of MIMSP, were probably eroded from the upper part of the inner perimeter ridge and deposited along with rhodoliths and mud in a shallow slope environment during exposure, or possibly incipient drowning, of the inner perimeter ridge.

The extreme moldic porosity of LPSC and UPSC probably developed by dissolution of aragonitic skeletons in deep, cold seawater throughout the Cenozoic, after the drowning of the Wodejebato Atoll. Small volumes of calcite cement were probably deposited concomitantly by cold seawater. Dissolution of some of the aragonite was by meteoric water before drowning, as indicated by Early Tertiary plankton in molds near the limestone surface. If the trough separating the inner and outer ridges is also a karst feature, most or all of the leaching of the underlying limestone may have resulted from this relatively 


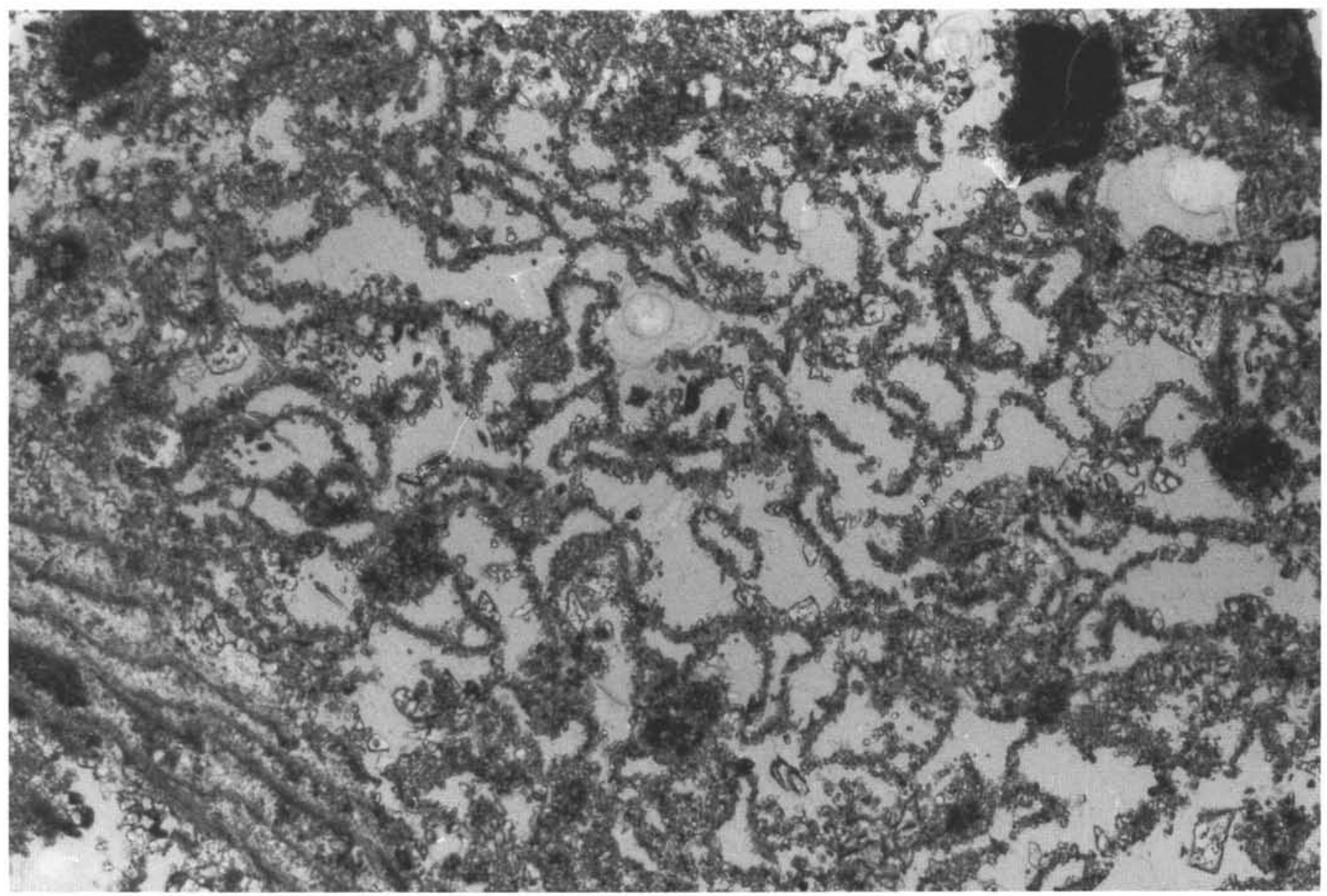

Figure 11. "Egg-shell porosity" formed by leaching of skeletal grains, whose outline is preserved by micrite envelopes. Cementation is by very finely crystalline, limpid, pyramidal crystals of calcite with uniform extinction (PLUC). Photomicrograph, plane light. Interval $144-876 \mathrm{~A}-5 \mathrm{R}-1,37-45 \mathrm{~cm}$. Maximum dimension is $2.5 \mathrm{~mm}$.

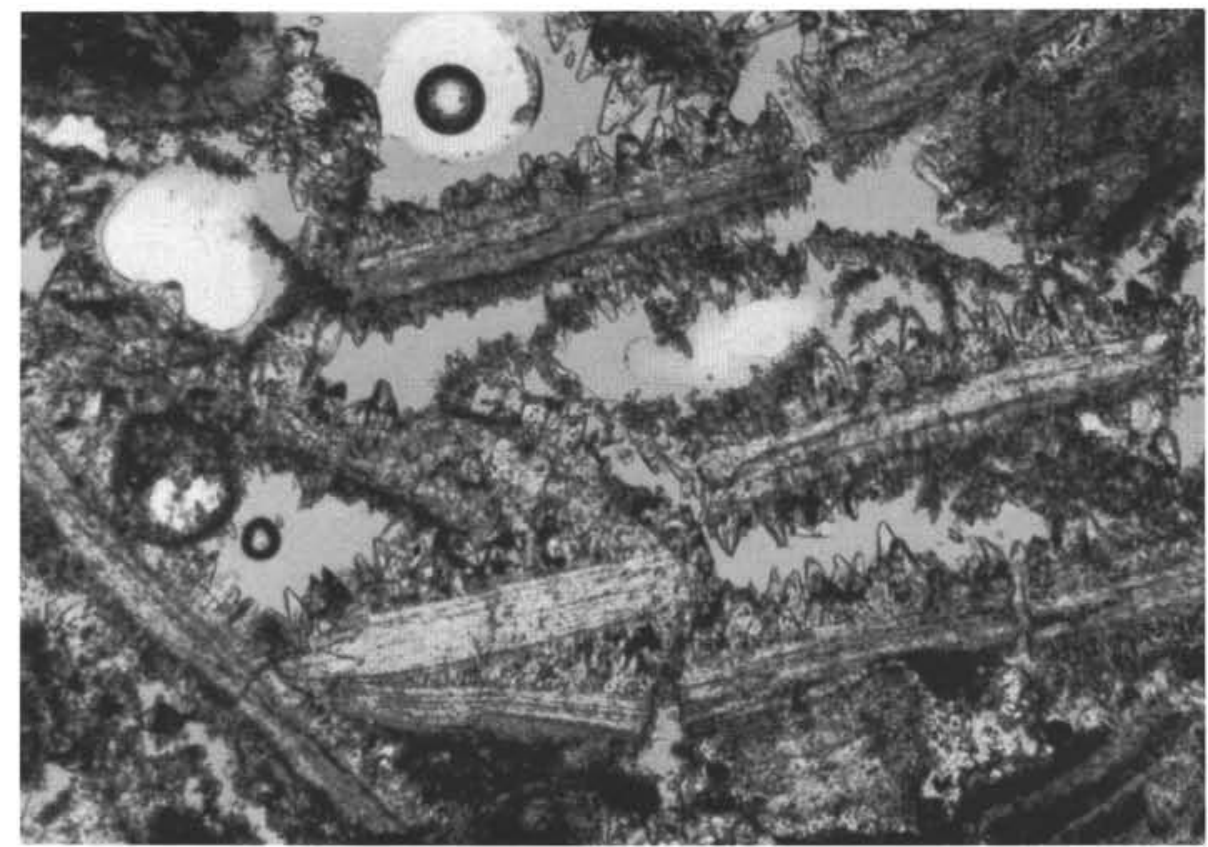

Figure 12. Mollusk fragments cemented by crusts of limpid, pyramidal crystals of calcite (PLUC). Cement crystals are commonly syntaxial with prisms of the mollusk shells. Fractures have slightly offset three fragments and their cement crusts, recording minimal compaction that followed cementation. Photomicrograph, plane light. Interval $144-876 \mathrm{~A}-4 \mathrm{R}-1,51-57 \mathrm{~cm}$. Maximum dimension is $1.6 \mathrm{~mm}$. 


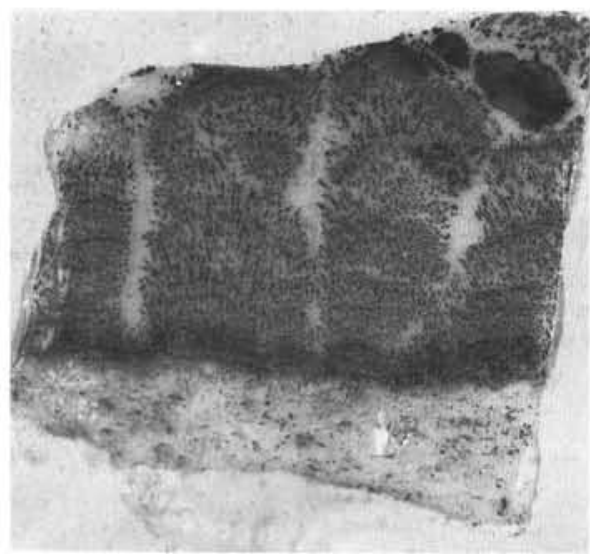

Figure 13. Contact between upper calcarenite (UPSC; below) and pelagic limestone. Manganese oxides encrust the contact and extend as dendrites into the pelagic limestone. Positive print of acetate peel. Interval 144-875C-1M-1, $7-14 \mathrm{~cm}$. Width of sample is $5 \mathrm{~cm}$.

brief exposure episode. The time available for this chemical erosion, 2.5 to 9 m.y., appears too brief to remove such a volume of carbonate, based on liberal calculations.

\section{ACKNOWLEDGMENTS}

Thanks to Jerry Winterer and Janet Haggerty, who persuaded Paul Enos to enlist for this adventure. Isabella, Janet, and Frank ran a good ship. Captain Ribbens and the crew kept us headed into the sunrise but landed us in Yokohama. The other three cultures on shipboardthe scientific, technical, and drilling crews-all did their jobs well. Special thanks to Gretchen Hampt, laboratory whip, in this regard. Doug Bergersen provided copious unpublished data and idea exchanges during the winter of discontent. Gigi Delgado, Jennifer Marin, and Eva M. Maddox, ODP/TAMU, kept the manuscript moving. Janet Haggerty, Peter Flood, and (especially) Charles Kahle improved it with critical reviews. Cyndee Ward processed my scribbles into this beautiful paper. Financial support from USSSAC Grant \#5182-0705 and the Merrill W. Haas Fund at Kansas kept the wolves from the door and made participation in the post-cruise meeting and field trips possible.

\section{REFERENCES}

Adey, W.H., and McIntyre, I.G., 1973. Crustose coralline algae: a re-evaluation in the geological sciences, Geol. Soc. Am. Bull., 84:883-904

Bathurst, R.G.C., 1975. Carbonate Sediments and Their Diagenesis (2nd ed.) Amsterdam (Elsevier)

Enos, Paul, 1977a. Tamabra Limestone of the Poza Rica Trend, Cretaceous, Mexico. In Cook, H.E., and Enos, Paul (Eds.), Deep-water Carbonate Environments. Spec. Publ.-Soc. Econ. Paleontol. Mineral., 273-314. $-1977 \mathrm{~b}$. Holocene sediment accumulations of the south Florida shelf margin. In Enos, Paul, and Perkins, R.D. (Eds.), Quaternary Sedimentation in South Florida. Mem.-Geol. Soc. Am., 147:1-130.

Enos, Paul, and Freeman, T., 1978. Shallow-water limestone from the Blake Nose, Sites 390 and 392. In Benson, W.E., Sheridan, R.E., et al., Init. Repts. DSDP, 44: Washington (U.S. Govt. Printing Office), 413-461.

Enos, Paul, and Sawatsky, L.H., 1981. Pore networks in Holocene carbonate sediments. J. Sediment. Petrol., 51:961-985.

Enos, Paul, and Stephens, B.P., 1993. Basin-margin carbonates, mid-Cretaceous, east-central, Mexico. Sedimentology, 40:539-556.

Folk, R.L., 1967. Sand cays of Alacran Reef, Yucatan, Mexico: morphology. J. Geol., 75:412-437.

Folk, R.L., and Robles, R., 1964. Carbonate sands of Isla Perez, Alacran ree complex, Yucatan. J. Geol., 72:255-292.

Ginsburg, R.N., 1956. Environmental relationships of grain size and constituent particles in some south Florida carbonate sediments. AAPG Bull., 40:2384-2427.
Harris, W.H., and Matthews, R.K., 1968. Subaerial diagenesis of carbonate sediments: efficiency of the solution-precipitation process. Science, 160:77-79.

Kauffman, E.G., and Sohl, N.F., 1974. Structure and evolution of Antillean Cretaceous rudist frameworks. Verh. Naturforsch. Ges. Basel, 84:399-467.

Krauskopf, K.B., 1967. Introduction to Geochemistry: New York (McGrawHill).

Lafon, G.M., and Vacher, H.L., 1975. Diagenetic reactions as stochastic processes: application to the Bermudian eolianites:Mem.-Geol. Soc. Am., 142:187-204.

Newell, N.D., and Rigby, J.K., 1957. Geological studies on the Great Bahama Bank. In Leblanc, R.J., and Breeding, J.G. (Eds.), Regional Aspects of Carbonate Deposition. Spec. Publ.-Soc. Econ. Paleontol. Mineral., 5:15-75.

Premoli Silva, I., Haggerty, J., Rack, F., et al., 1993. Proc. ODP, Init. Repts., 144: College Station, TX (Ocean Drilling Program).

Schlager, W., and James, N.P., 1978. Low-magnesian calcite limestones forming at the deep-sea floor, Tongue of the Ocean, Bahamas. Sedimentology, $25: 675-702$.

Vacher, H.L., Bengtsson, T.O., and Plummer, L.N., 1990. Hydrology of meteoric diagenesis: residence time of meteoric ground water in island fresh-water lenses with application to aragonite-calcite stabilization rate in Bermuda. Geol. Soc. Am. Bull., 102:223-232.

\footnotetext{
- Abbreviations for names of organizations and publications in ODP reference lists follow the style given in Chemical Abstracts Service Source Index (published by American Chemical Society).
}

Date of initial receipt: 2 February 1994

Date of acceptance: 15 September 1994

Ms 144SR-036

\section{APPENDIX}

\section{Calculation of Dissolution Periods}

The time required for some of the dissolution scenarios proposed can be calculated from solution chemistry and mass-balance considerations (cf. Enos and Sawatsky, 1981). For example, the time to remove a layer of calcareous sediment $1.3 \mathrm{~m}$ thick, the approximate relief observed on the postulated Cretaceous microkarst surface on Wodejebato Guyot, can be estimated at nearly half a million years.

Assume that the initial grainstone bed had about $45 \%$ porosity (Enos and Sawatsky, 1981, p. 961) and was composed entirely of aragonite with grain density of $2.94 \mathrm{~g} / \mathrm{cm}^{3}$. The mass of $\mathrm{CaCO}_{3}$ removed to lower the surface 1.3 $\mathrm{m}$ would be $130 \mathrm{~cm} \times(1-0.45) \times 2.94 \mathrm{~g} / \mathrm{cm}^{3} / \mathrm{cm}^{2}=210 \mathrm{~g} / \mathrm{cm}^{2}$. The solubility product of aragonite, $K_{\text {arag }}=10^{-8.22}$ (Krauskopf, 1967), yields a solubility of $7.8 \times 10^{-3} \mathrm{~g} / \mathrm{l}$ with the gram-molecular weight of 100 for $\mathrm{CaCO}_{3}$. Uncemented skeletal grainstones have permeabilities of around 31,000 millidarcies (Enos and Sawatsky, 1981). This is enough to transmit virtually any amount of rainfall, so that climate becomes the controlling factor in dissolution rates. In the absence of any reliable meteorologic data from the Central Pacific in the latest Cretaceous, we can use modern data from south Florida, which has a humid subtropical climate and comparable carbonate aquifer characteristics, as an approximation. Annual rainfall is $152 \mathrm{~cm} / \mathrm{yr}$ (60 in./yr); evapotranspiration from the soil and water table totals $89 \mathrm{~cm}^{3} / \mathrm{yr} / \mathrm{cm}^{2}$, leaving a net groundwater discharge of $63 \mathrm{~cm}^{3} / \mathrm{yr} / \mathrm{cm}^{2}$ (Enos and Sawatsky, 1981, p. 980). This is the amount available to dissolve and transport carbonate. At a solubility of 7.8 $\times 10^{-3} \mathrm{~g} / \mathrm{l}$, it would require $210 / 7.810^{-3}=2.69 \times 10^{4}$ liters of water to dissolve $1.3 \mathrm{~m}$ of carbonate from an area of $1 \mathrm{~cm}^{2}$. At $63 \mathrm{~cm}^{3} / \mathrm{yr} / \mathrm{cm}^{2}, 2.70 \times 10^{4} \times$ $10^{3} / 63=428,000 \mathrm{yr}$ are required. Were the sediment entirely calcite $\left(K_{\mathrm{cal}}=\right.$ $10^{-8.34} ; r=2.71 \mathrm{~g} / \mathrm{cm}^{3}$ ), $452,000 \mathrm{yr}$ would be required.

If this type of reasoning is extended to remove $70 \mathrm{~m}$ of sediment to form the trough between the inner and outer ridges, $23 \mathrm{~m}$.y. would be required if the sediment were aragonite. This time can be cut in half by assuming a V-shaped trough rather than a rectangular parallelepiped (i.e., to $11.5 \mathrm{~m}$.y.). If the trough is only $45 \mathrm{~m}$ deep (Fig. 2), the average relief of the inner and outer ridges is used for the depth of the trough on the assumption of a linear gradient.), 7.4 m.y. would be required.

Similarly, the time required to form the moldic porosity in the rocks of the outer perimeter ridge can be estimated. For example, the upper unit (UPSC) is $105.4 \mathrm{~m}$ thick at Site 875 and averages $38.8 \%$ porosity (Premoli Silva, Haggerty, Rack, et al., 1993, pp. 262 and 267), of which $35.7 \%$ is secondary 
(Table 2). To create this porosity requires the removal of $10,540 \mathrm{~cm}^{3} \times 0.388$ $\times 0.357=1460 \mathrm{~cm}^{3}$ of aragonite, or $4.292 \mathrm{~g}$ at $\rho=2.94 \mathrm{~g} / \mathrm{cm}^{3}$. At a solubility of $7.8 \times 10^{-3} \mathrm{~g} /$ liter, 550,300 liters of water are required $\left(550.3 \times 10^{6} \mathrm{~cm}^{3}\right)$. At $63 \mathrm{~cm}^{3} / \mathrm{yr} / \mathrm{cm}^{2}$, this amount of water requires $550.3 \times 10^{6} / 63=8.735$ m.y. Calculated times for each unit at each site are given in the Appendix table. The total time required would be 10.5 m.y. at Site 875 and 11.5 m.y. at Site 876 .

These calculations do not expressly take into account two significant factors. A single volume of water could dissolve more than the calculated mass of aragonite, if it concomitantly precipitates calcite and thereby remains undersaturated with regard to aragonite (cf. Harris and Matthews, 1968). This would reduce the time required. Only extant dissolution porosity was considered in the calculations; no correction was made for cement-reduced secondary porosity. These two effects are related and should largely cancel each other. A more conservative correction would be to consider all cement, whether in primary or secondary pores, as deriving from dissolution of aragonite. This would overcompensate, because cryptocrystalline carbonate consumed in lithification of matrix mud, lithification of soft pellets, and cementation of micrite envelopes would not be accounted for, nor would any net transport of carbonate from the system.

Note that the total time required for all the events considered here would be cumulative, as each is controlled by the available ground-water discharge. Thus, the total time required would be 18.4-22.5 m.y., depending on the depth of the inter-ridge trough. Either of these numbers is greater than the late Maastrichtian to late Paleocene interval available for subaerial exposure (11 m.y. for the inner ridge; 9 m.y. for the outer ridge), suggesting that meteoric leaching alone could not be responsible for all the observed dissolution.

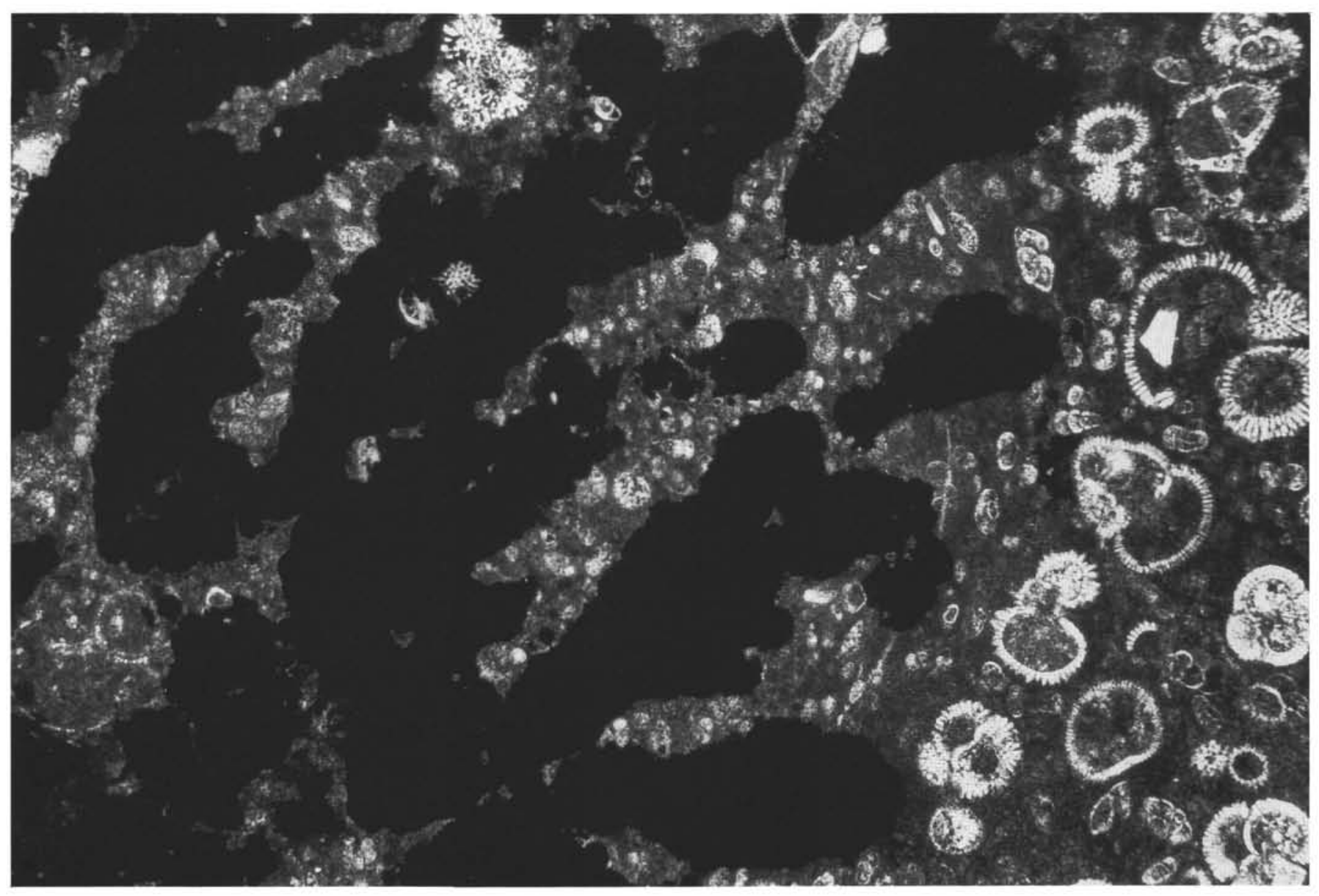

Figure 14. Manganese-oxide dendrites replacing pelagic limestone. Thin-section photomicrograph, plane light. Interval $144-876 \mathrm{~A}-1 \mathrm{R}-1,37-42 \mathrm{~cm}$. This is adjacent to the vertical contact figured in Premoli Silva, Haggerty, Rack, et al. (1993, p. 266). Maximum dimension is $3.2 \mathrm{~mm}$.

\section{APPENDIX}

Calculated Times to Produce Observed Dissolution Porosities by Unit and Site for Wodejebato Outer Ridge

\begin{tabular}{lcccccccc}
\hline Unit & Site & $\begin{array}{c}\text { Thickness } \\
(\mathrm{m})\end{array}$ & $\begin{array}{c}\text { Porosity } \\
(\%)\end{array}$ & $\begin{array}{c}\text { Secondary } \\
(\%)\end{array}$ & $\begin{array}{c}\text { Volume } \\
\text { removed } \\
\left(\mathrm{cm}^{3}\right)\end{array}$ & $\begin{array}{c}\text { Mass } \\
\text { removed } \\
(\mathrm{g})\end{array}$ & $\begin{array}{c}\text { Water } \\
\text { required } \\
\left(\mathrm{cm}^{3} \times 10^{6}\right)\end{array}$ & $\begin{array}{c}\text { Time } \\
\text { required } \\
(\mathrm{m} . y .)\end{array}$ \\
\hline UPSC & 875 & 105.4 & 38.8 & 35.7 & 1460 & 4292 & 550.3 & 8.735 \\
UPSC & 876 & 98 & 40.1 & 37.3 & 1466 & 4309 & 552.5 & 8.77 \\
MIMSP & 875 & 8.4 & 16.1 & 33.3 & 45 & 132 & 17.0 & 0.269 \\
MIMSP & 876 & 10 & 5.8 & 62.2 & 38 & 113 & 14.5 & 0.230 \\
LPSC & 865 & 12.1 & 28.8 & 72.9 & 254 & 747 & 95.8 & 1.520 \\
LSPC & 876 & 37.5 & 35.1 & 32.5 & 428 & 1258 & 161.2 & 2.559 \\
\hline
\end{tabular}

Note: Assumptions are outlined in the accompanying text (see Appendix). 